Prepared in cooperation with the Natural Resources Conservation Service-North Dakota

\title{
Small Basin Annual Yield and Percentage of Snowmelt Runoff in North Dakota, 1931-2016
}

Scientific Investigations Report 2019-5144 



\section{Small Basin Annual Yield and Percentage of Snowmelt Runoff in North Dakota, 1931-2016}

By Tara Williams-Sether and Spencer L. Wheeling

Prepared in cooperation with the Natural Resources Conservation ServiceNorth Dakota

Scientific Investigations Report 2019-5144 


\title{
U.S. Department of the Interior \\ DAVID BERNHARDT, Secretary
}

\author{
U.S. Geological Survey \\ James F. Reilly II, Director
}

U.S. Geological Survey, Reston, Virginia: 2020

For more information on the USGS - the Federal source for science about the Earth, its natural and living resources, natural hazards, and the environment—visit https://www.usgs.gov or call 1-888-ASK-USGS.

For an overview of USGS information products, including maps, imagery, and publications, visit https://store.usgs.gov/.

Any use of trade, firm, or product names is for descriptive purposes only and does not imply endorsement by the U.S. Government.

Although this information product, for the most part, is in the public domain, it also may contain copyrighted materials as noted in the text. Permission to reproduce copyrighted items must be secured from the copyright owner.

Suggested citation:

Williams-Sether, T., and Wheeling, S.L., 2020, Small basin annual yield and percentage of snowmelt runoff in North Dakota, 1931-2016: U.S. Geological Survey Scientific Investigations Report 2019-5144, 37 p., https://doi.org/ 10.3133/sir20195144.

Associated data for this publication:

U.S. Geological Survey, 2017, USGS water data for the Nation: U.S. Geological Survey National Water Information System database, https://doi.org/10.5066/F7P55KJN.

ISSN 2328-0328 (online) 


\section{Acknowledgments}

The authors wish to thank local, State, and Federal agencies that have cooperated in the support of the operation and maintenance of streamgages and climatic gages used in this study.

The authors also wish to thank Pete McCarthy of the U.S. Geological Survey for his assistance in streamflow record extension by writing and running an $\mathrm{R}$ program to implement the modified Maintenance of Variance Extension Type III application and for providing the estimated annual streamflow volumes used in this study. 



\section{Contents}

Acknowledgments ……...................................................................................................................

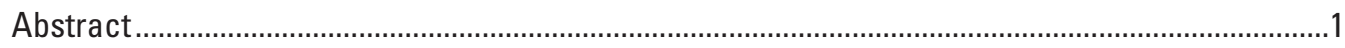

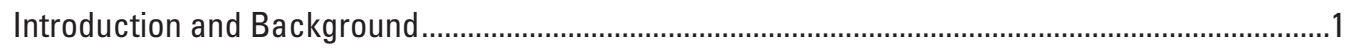

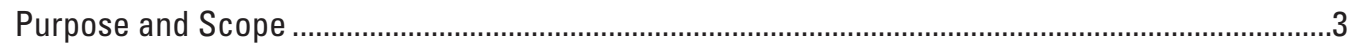

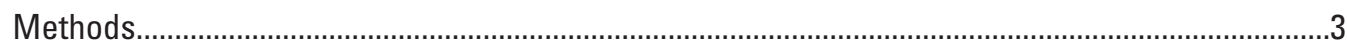

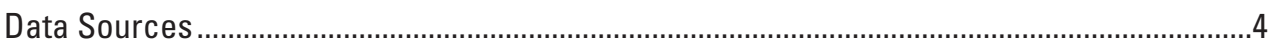

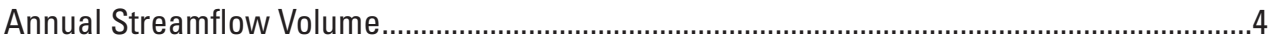

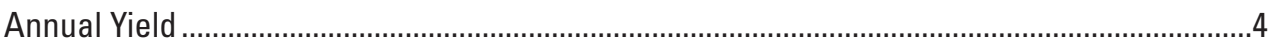

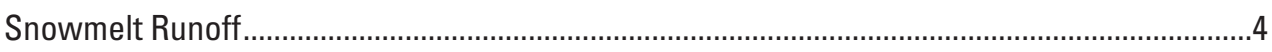

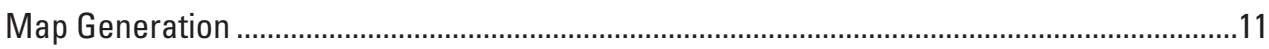

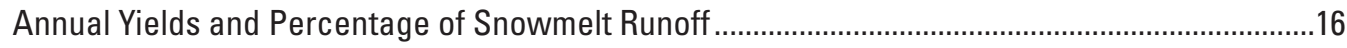

Summary

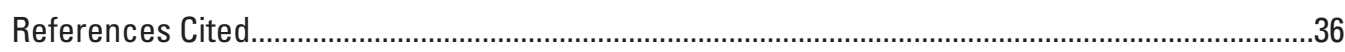

Appendix 1. Methods Used to Generate and Adjust Annual Streamflow Volumes Used in Move.3.....................................................................................................................

Appendix 2. R Code Script and Supporting Data for the Modified Maintenance of Variance Extension Type III, MOVE.3, Application

\section{Figures}

1. Maps showing annual yield maps in chapter 7 of the North Dakota hydrology manual

2. Map showing locations of streamgages used to estimate annual yield percentage exceedance probabilities and expected percentage of snowmelt runoff

3. Map showing locations of climatic stations used to estimate alternate expected percentage of snowmelt runoff

4. Map showing expected percentage of snowmelt runoff isolines for 1941-70 using November-May climatic data

5. Maps showing expected percentage of snowmelt runoff isolines for 1941-70 using streamflow data

6. Maps showing expected percentage of snowmelt runoff isolines for 1941-70 with drainage areas of 505 square miles or less using streamflow data.

7. Maps showing annual yield using 131 selected streamgages and a period of record of 1941-70 with 10-percent or less missing record.

8. Maps showing annual yield at the 50-percent exceedance probability using 1931-2016 data with streamgages that have 10-percent or less missing calculated and estimated annual volumes and a drainage area of 505 square miles or less and allowing the 1931-2016 data to have a missing record for expected percentage of snowmelt runoff 
9. Maps showing annual yield at the 80 -percent exceedance probability using 1931-2016 data with streamgages that have 10-percent or less missing calculated and estimated annual volumes and a drainage area of 505 square miles or less and allowing the 1931-2016 data to have a missing record for expected percentage of snowmelt runoff

10. Maps showing annual yield at the 50-percent exceedance probability using 1931-2016 data with streamgages that have 10-percent or less missing annual volume record and 50 percent or less of Maintenance of Variance Extension Type III annual volume estimations and a drainage area of 505 square miles or less and allowing the 1931-2016 data to have a missing record for expected percentage of snowmelt runoff.

11. Maps showing annual yield at the 80-percent exceedance probability using 1931-2016 data with streamgages that have 10-percent or less missing annual volume record and 50 percent or less of Maintenance of Variance Extension Type III annual volume estimations and a drainage area of 505 square miles or less and allowing the 1931-2016 data to have a missing record for expected percentage of snowmelt runoff.

\section{Tables}

1. Hydrologic and basin characteristics for streamgages used...........................................

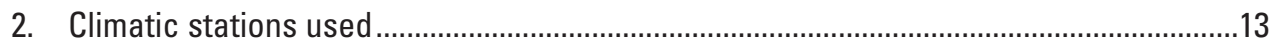

3. Example application of Weibull plotting for U.S. Geological Survey station 05066500 for the $1941-70$ period of record 


\section{Conversion Factors}

U.S. customary units to International System of Units

\begin{tabular}{lcl}
\hline \multicolumn{1}{c}{ Multiply } & By & \multicolumn{1}{c}{ To obtain } \\
\hline inch (in.) & Area & \\
acre & 2.54 & centimeter $(\mathrm{cm})$ \\
square mile $\left(\mathrm{mi}^{2}\right)$ & 4,047 & square meter $\left(\mathrm{m}^{2}\right)$ \\
\hline & 2.590 & square kilometer $\left(\mathrm{km}^{2}\right)$ \\
\hline acre-foot (acre-ft) & Volume & \\
\hline
\end{tabular}

\section{Datum}

Horizontal coordinate information is referenced to the North American Datum of 1983 (NAD 83).

\section{Supplemental Information}

A water year is the period from 0 ctober 1 to September 30 and is designated by the year in which it ends; for example, water year 2015 was from October 1, 2014, to September 30, 2015.

\section{Abbreviations}

MOVE.3 Maintenance of Variance Extension Type III

USGS U.S. Geological Survey 



\title{
Small Basin Annual Yield and Percentage of Snowmelt Runoff in North Dakota, 1931-2016
}

\author{
By Tara Williams-Sether and Spencer L. Wheeling
}

\begin{abstract}
The North Dakota hydrology manual prepared by the U.S. Department of Agriculture, Soil Conservation Service, presents methodologies primarily used for developing hydrology for onfarm conservation practices, watershed projects, Resource Conservation and Development project measures, and river basin studies. The manual includes data necessary for determining hydrologic factors and developing a design discharge for a given site and intended purpose. The U.S. Geological Survey, in cooperation with the North Dakota Natural Resources Conservation Service, developed methods to reproduce and update the annual yield maps for chapter 7 of the North Dakota hydrology manual. Annual yields, in acre-feet per square mile, for the 50- and 80-percent exceedance probabilities and expected percentage of snowmelt runoff isolines were estimated using U.S. Geological Survey streamflow data from 1931 to 2016 for 71 selected streamgages with drainage areas of 505 square miles or less. An application of a modified Maintenance of Variance Extension Type III was used to estimate missing annual streamflow volumes. An alternate expected percentage of snowmelt runoff isolines was estimated using High Plains Climatic Center precipitation and snowmelt data from 1931 to 2016 for 85 selected sites. The final expected percentage of snowmelt runoff isolines was estimated using streamflow data instead of precipitation and snowfall depth data. A snowmelt runoff seasonal period of March-May produced better isoline slopes than a November-May runoff seasonal period. Slopes of the expected percentage of snowmelt runoff isolines were sensitive to amounts of missing record. Suitable isoline slopes appeared when the missing record was set to 50 percent (43 years) and 66 percent (57 years) for the 86 -year period of 1931-2016.
\end{abstract}

\section{Introduction and Background}

The North Dakota hydrology manual (Soil Conservation Service, 1974) was prepared by the U.S. Department of Agriculture, Soil Conservation Service, to assist in planning and design measures for soil and water conservation practices and flood prevention measures in North Dakota. The manual includes data necessary for determining hydrologic factors and developing a design discharge for a given site and intended purpose. The methodology presented in the manual is primarily used for developing hydrology for onfarm conservation practices, watershed projects, Resource Conservation and Development project measures, and river basin studies. The maps of chapter 7 of the North Dakota hydrology manual are of particular interest to the North Dakota Natural Resources Conservation Service.

Annual runoff from a watershed has a direct relation to the watershed yield. Yield is defined as a flow volume over a set period. Chapter 7 of the North Dakota hydrology manual describes watershed yield as being used in the planning and design of water resource projects, commonly involving irrigation; recreational water storage; and municipal and industrial water supplies. The term watershed yield, however, is somewhat loosely used in the literature and can refer either to a long-term average (for example, 1971-2000 average annual streamflow) or can be synonymous with runoff volume for a specific period (such as flow for May 1999; Natural Resources Conservation Service, 2009).

Watershed water yield can be estimated several ways. Methods chosen depend upon data availability and the desired seasonal periods. Three ways to estimate watershed water yield are (1) runoff (yield) maps, (2) regression equations, and (3) water balance. The methods used to develop the annual yield maps (fig. 1) in chapter 7 of the North Dakota hydrology manual (hereafter referred to as the "chapter 7 annual yield maps") are unknown, because no documentation is provided within the manual; however, U.S. Geological Survey (USGS) streamgages were used in the development of the chapter 7 annual yield maps.

Determination and documentation of annual yield map development methods along with updated chapter 7 annual yield maps would provide essential data for identifying and mitigating wetlands, locally for individual land owners and across North Dakota. This information would also increase understanding of development of annual yield maps and expected percentage of snowmelt runoff isolines for North Dakota. To address these needs, the USGS, in cooperation with the North Dakota Natural Resources Conservation Service, completed a study to determine small basin annual yield and percentage of snowmelt runoff in North 
A. 50-percent exceedance probability

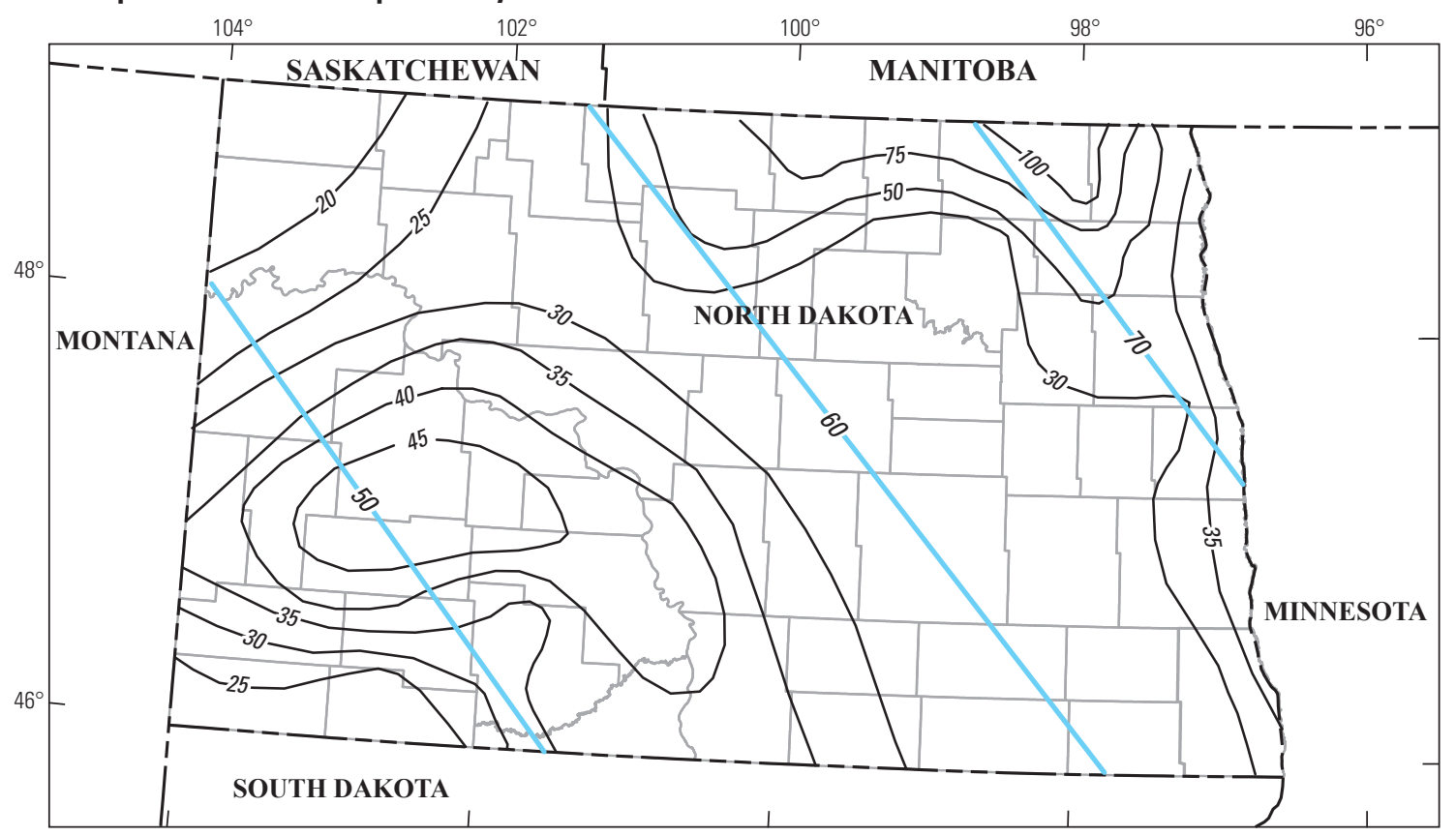

B. 80-percent exceedance probability

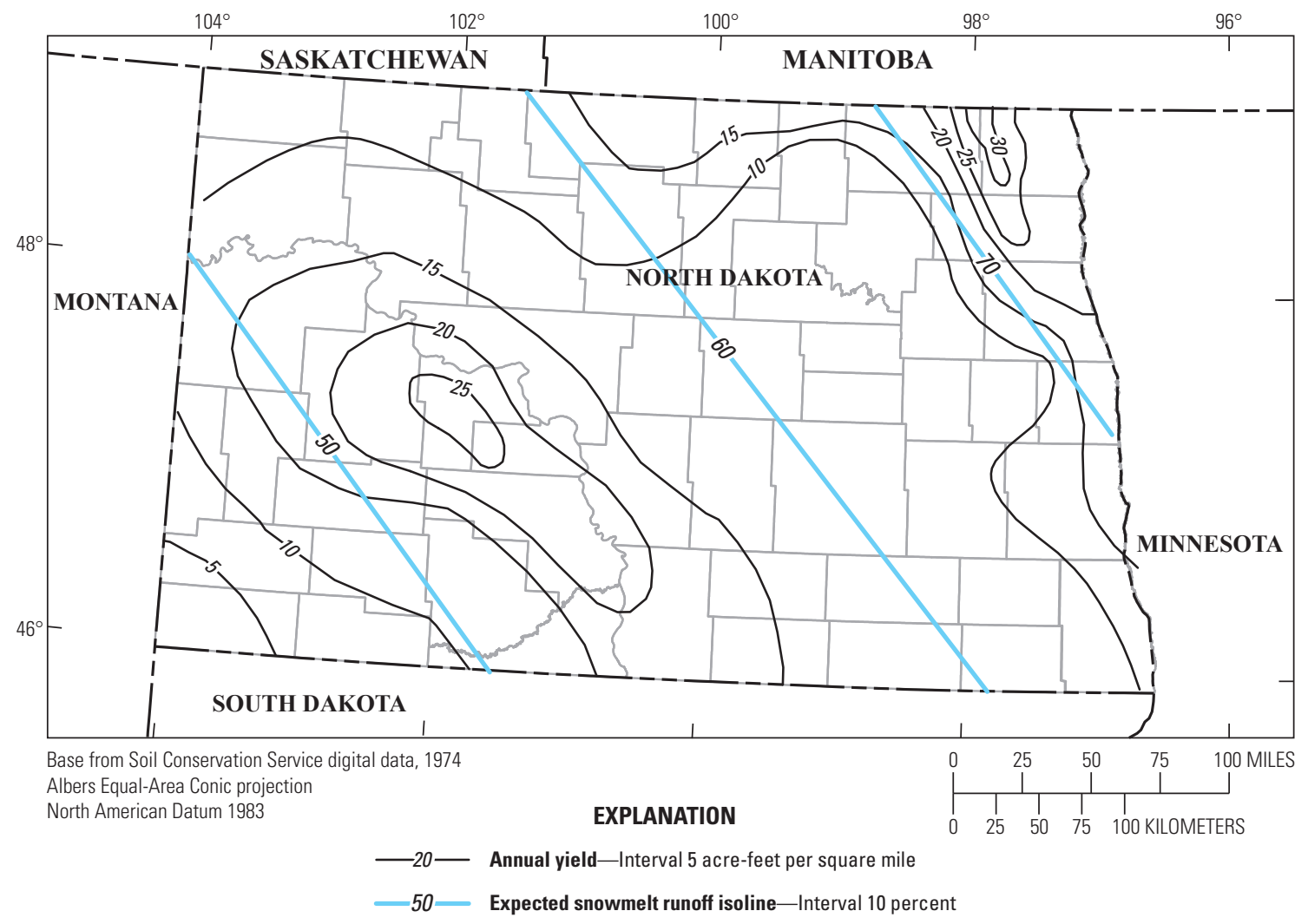

Figure 1. Annual yield maps in chapter 7 of the North Dakota hydrology manual (modified from Soil Conservation Service, 1974). $A$, 50-percent exceedance probability; $B$, 80-percent exceedance probability. 
Dakota. This study had two specific objectives. The first objective was to attempt to reproduce the chapter 7 annual yield maps. The second objective was to use streamflow data from 1931 to 2016 to produce updated maps similar to the earlier maps.

\section{Purpose and Scope}

The purpose of this report is to present and describe small basin annual yield and percentage of snowmelt runoff in North Dakota for 1931-2016 using annual yield maps. This report also describes methods used to develop the annual yield maps that reproduce and update the chapter 7 annual yield maps of the North Dakota hydrology manual (Soil Conservation Service, 1974). The chapter 7 annual yield maps consist of two parts: (1) an annual yield contour map and (2) an expected percentage of snowmelt runoff isoline map. Annual yield and expected percentage of snowmelt runoff isoline estimates were based on daily mean streamflow data from 131 selected USGS streamgages in North Dakota and parts of Montana, South Dakota, and Minnesota. Alternate expected percentage of snowmelt runoff isoline estimates were based on 85 selected climate stations in North Dakota. Available climatic data from 1931 to 2016 were used.

\section{Methods}

The chapter 7 annual yield maps present two types of information: (1) the annual yield, in acre-feet per square mile, for the 50- and 80-percent exceedance probabilities and (2) the expected percentage of snowmelt runoff. Annual yield for the 50- and 80-percent exceedance probabilities and expected percentage of snowmelt runoff was estimated for 30-year normal periods 1941-70, 1981-2010, and 1987-2016. Additionally, the 86-year period 1931-2016 also was analyzed. Because the exact period of data used in the development of the chapter 7 annual yield maps was unknown, the 30 -year normal period of 1941-70 was chosen to determine possible methodologies of the chapter 7 annual yield map development because the North Dakota hydrology manual was developed before 1974.

Streamflow records from the selected streamgages (U.S. Geological Survey, 2017) used in this study varied in length, and a consistent record length from 1931 to 2016 was desired. Consistent streamflow record lengths were achieved using a modified Maintenance of Variance Extension Type III (MOVE.3; Sando and McCarthy, 2018) to extend annual streamflow volume records. The modified MOVE. 3 procedures generally follow the MOVE. 3 methods of Vogel and Stedinger (1985), which involve synthesis of missing records for a short-record streamgage based on information collected from a single, longer-record streamgage (Sando and McCarthy, 2018). The modified MOVE. 3 procedures require at least 7 or 8 years of concurrent peak-flow records for the target and index streamgages with a Pearson correlation coefficient greater than 0.80; and in some cases, uses a mixed-streamgage approach for the MOVE. 3 procedure such that multiple index streamgages are used to synthesize missing records for a single target streamgage (Sando and McCarthy, 2018). Further details of the modified MOVE. 3 procedures are discussed in Sando and McCarthy (2018).

A Weibull plotting formula (Loucks and others, 1981) was applied to determine the percentage exceedance probability of the annual yield, in acre-feet per square mile, for each data period chosen (1941-70, 1981-2010, 1987-2016, and 1931-2016). Linear interpolation was used where needed to estimate annual yield values at the 50- and 80-percent exceedance probabilities. Percentage exceedance probability values were plotted at streamgage locations using latitude and longitude, and the program Surfer ${ }^{\circledR} 15$ (Golden Software, 2018) was used to generate a contour map using kriging methodology (Oliver and Webster, 1990). Kriging is a method of spatial interpolation that was used to generate an estimated surface model from the percentage exceedance probability value ( $z$-value) of a scattered set of data points and is further explained within the Surfer program.

Daily mean streamflow records (U.S. Geological Survey, 2017) were used to determine the expected percentage of snowmelt runoff. The expected percentage of runoff attributed to snowmelt was calculated for each site using a period of record averaged ratio of summed daily streamflow per total annual streamflow for a selected period. Seasonal periods of November-May, March-May, and February-May 15 and an annual period (based on water year, which is October 1 to September 30) were used to determine the ratios. The period of record for each site used available data through 2016 and included expected percentage runoff averages for the chosen 30-year normal periods of 1941-70, 1981-2010, and 1987-2016 and the 86-year period of 1931-2016. The expected percentage of snowmelt runoff averages were plotted at streamgage locations using latitude and longitude and isolines generated by fitting a linear regression through the planar data using the Surfer ${ }^{\circledR} 15$ program.

Monthly and annual climate records of precipitation and snowfall also were used to determine an alternate expected percentage of snowmelt runoff isoline. Snowfall depths were converted to water equivalents using a ratio of 10 inches (in.) of snow to 1 in. of water depth (National Weather Service, 2019). The expected percentage of runoff attributed to snowmelt was calculated for each site using a period of record averaged ratio of total snow water equivalent per total precipitation for the selected 30-year normal periods of 1941-70 and 1981-2000 and the 86-year period of 1931-2016. A seasonal period (November-May) and an annual period (by water year, October-September) were used to determine the ratios. The expected percentage of snowmelt runoff averages for 1941-70 were plotted at climate station locations using latitude and longitude and isolines generated by fitting a linear regression through the planar data using the Surfer ${ }^{\circledR} 15$ program (Golden Software, 2018). 


\section{Data Sources}

The data used in this study consisted of (1) daily mean streamflow records for 131 selected streamgages in North Dakota and parts of Montana, South Dakota, and Minnesota (fig. 2, table 1); (2) monthly and annual precipitation and snow depth totals for selected climate stations in North Dakota (fig. 3, table 2); and (3) selected basin characteristics (table 1). All available streamflow and climatic data were retrieved through 2016. Daily mean streamflow records were retrieved from the USGS National Water Information System (U.S. Geological Survey, 2017), a comprehensive and distributed application that supports the acquisition, processing, and long-term storage of water data.

The selected basin characteristics in table 1 (latitude, longitude, and drainage area) for the 131 selected streamgages were retrieved from Williams-Sether (2015) where available. Drainage areas for streamgages not included in WilliamsSether (2015) were estimated using State applications of StreamStats (U.S. Geological Survey, 2018). StreamStats is a USGS web application that provides access to an assortment of geographic information systems analytical tools that are useful for water-resources planning and management and for engineering and design purposes.

Monthly and annual precipitation and snow depth data of sites listed in table 2 were retrieved from the High Plains Regional Climate Center (High Plains Regional Climate Center, 2018). The High Plains Regional Climate Center provides the public with several ways to access climate data and information. Through various data acquisition methods, users can access a variety of climate data products such as near real-time and historical climate data; national and regional climate data maps; agricultural climate products; and monthly, quarterly, and annual regional climate summaries.

\section{Annual Streamflow Volume}

Annual streamflow volumes, in acre-feet, for the 131 selected streamgages were calculated by summing daily mean records, in cubic feet per second, and multiplying by 1.9835 (conversion from cubic feet per second to acre-feet) for each water year of record. Calculating the annual streamflow volumes per year required that a full water year (October 1 through September 30 of the following year) of daily mean record existed for the selected streamgages. However, sometimes a full annual record was not available and only seasonal (for example, March 1 through September 30) daily mean values existed. When the summed annual volume record count was less than 365 days (or 366 days for a leap year) but included at least 214 days, an averaged ratio method was applied to convert the 214-day (as an example) summed annual volume to a volume based on a 365 -day count. For example, a streamgage has 214 days of data records during the year. For the exact same days (214), the volume sums were determined for all years that had 365 days. Ratios of volumes for 365/214-day counts were averaged over the years that had full counts of 365 days. A graphical plot was made of the 365/214 ratio versus the 214-day count volumes to identify any years that may be outliers. Visually identified outlying years were removed, and the average $365 / 214$ ratio was recalculated. The final averaged 365/214 ratio value was then multiplied by all years that had 214-day count volumes to convert them to 365 -day count volumes. The process was repeated as needed for other day counts greater than 214 days, such as 273 days. An example of this procedure is provided in appendix 1.

The modified MOVE. 3 procedure (Sando and McCarthy, 2018) was then used to estimate annual streamflow volumes for the years where daily count was less than 214 days. A minimum of 7 years of concurrent annual volume records for the target and index streamgages with a slightly relaxed Pearson correlation coefficient of 0.70 were used in the modified MOVE. 3 procedure. A description of the record-extension procedures and $\mathrm{R}$ code to run the modified MOVE. 3 procedure are provided in appendix 2 .

\section{Annual Yield}

The 50- and 80-percent exceedance probabilities for annual yield, in acre-feet per square mile, were determined by applying the Weibull plotting formula (Loucks and others, 1981) to each streamgage for each data period chosen. For each streamgage, the annual streamflow volumes, in acrefeet, were divided by the streamgage drainage area, in square miles. The values were then ranked from largest to smallest and assigned the associated plotting percentages calculated by equation 1.

$$
P=\frac{n}{m+1} \times 100
$$

where

$\begin{array}{cl}P & \text { is the Weibull plotting percentage, } \\ n & \text { is the rank number, and } \\ m & \text { is the number of data in period. }\end{array}$

The 50- and 80-percent exceedance probabilities were determined by interpolation of the ranked annual yield values based upon the Weibull plotting percentages for each period. An example is provided in table 3 .

\section{Snowmelt Runoff}

Daily mean streamflow data and climatic data, respectively, were used to determine the expected percentage of snowmelt runoff. Using streamflow data, the expected percentage of snowmelt runoff was calculated for each selected streamflow site using a period of record averaged ratio of summed daily mean streamflow per total annual streamflow for a selected period. Seasonal periods of November-May, March-May, and February-May 15 and an annual period (by water year, October-September) were used to determine the 


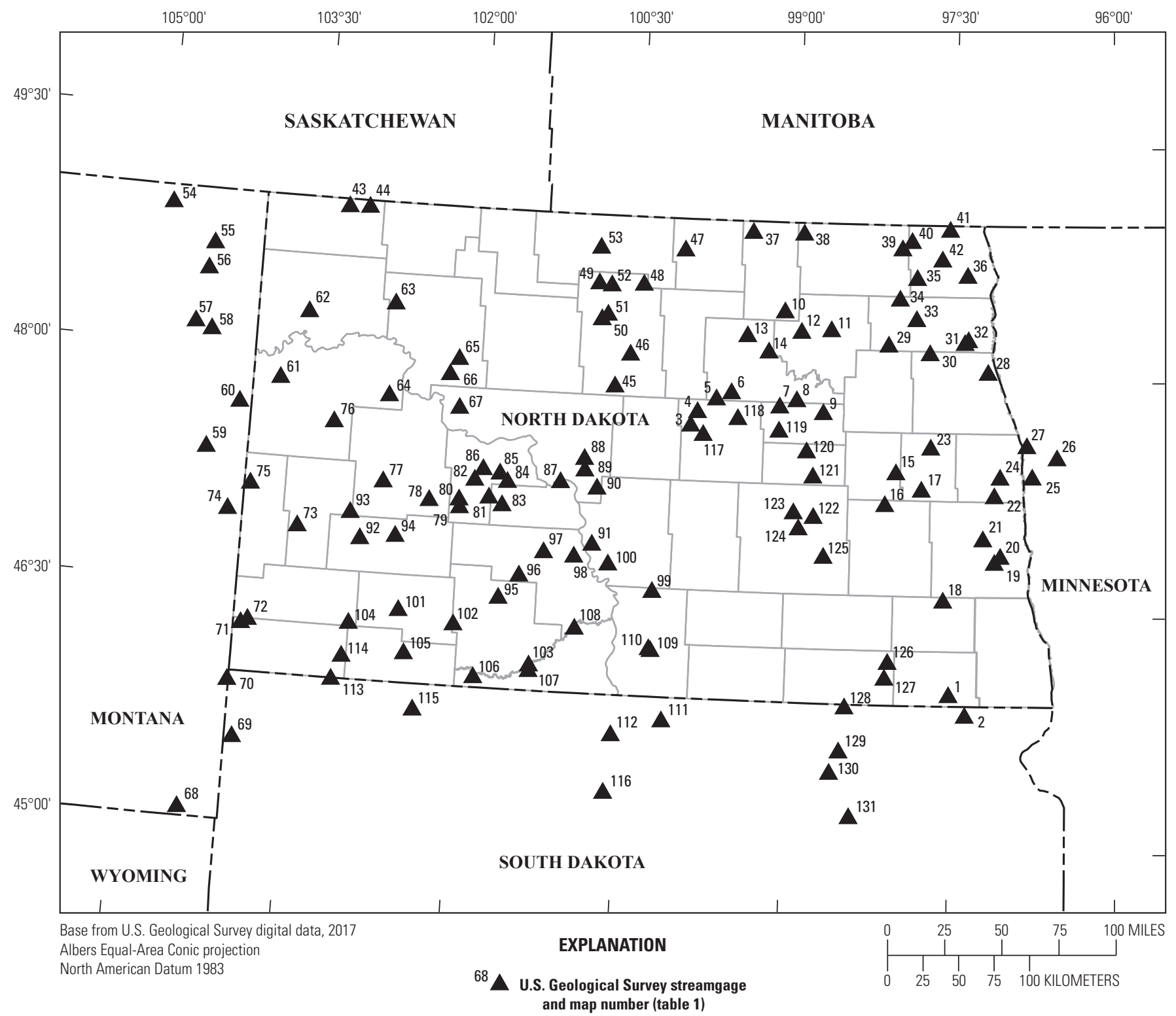

Figure 2. Locations of streamgages used to estimate annual yield percentage exceedance probabilities and expected percentage of snowmelt runoff. 
Table 1. Hydrologic and basin characteristics for streamgages used.

[Data from Williams-Sether (2015) unless otherwise noted. N. Dak., North Dakota; S. Dak., South Dakota; Minn., Minnesota; Mont., Montana; no., number]

\begin{tabular}{|c|c|c|c|c|c|}
\hline $\begin{array}{c}\text { Map } \\
\text { number } \\
\text { (fig. 2) }\end{array}$ & $\begin{array}{l}\text { U.S. Geological Survey } \\
\text { station number }\end{array}$ & $\begin{array}{l}\text { U.S. Geological Survey } \\
\text { station name }\end{array}$ & $\begin{array}{c}\text { Latitude } \\
\text { (decimal degrees) }\end{array}$ & $\begin{array}{c}\text { Longitude } \\
\text { (decimal degrees) }\end{array}$ & $\begin{array}{l}\text { Drainage area } \\
\text { (square miles) }\end{array}$ \\
\hline 1 & 05051600 & $\begin{array}{l}\text { Wild Rice River near Rutland, } \\
\text { N. Dak. }\end{array}$ & 46.0220 & -97.5115 & 503 \\
\hline 2 & 05051650 & $\begin{array}{l}\text { La Belle Creek near Veblen, } \\
\text { S. Dak. }\end{array}$ & 45.8925 & -97.3619 & 9.45 \\
\hline 4 & 05055000 & $\begin{array}{l}\text { Sheyenne River near Harvey, } \\
\text { N. Dak. }\end{array}$ & 47.7903 & -99.8908 & 500 \\
\hline 5 & 05055100 & $\begin{array}{l}\text { North Fork Sheyenne River near } \\
\text { Wellsburg, N. Dak. }\end{array}$ & 47.8761 & -99.7185 & 461 \\
\hline 8 & 05055520 & $\begin{array}{l}\text { Big Coulee near Fort Totten, } \\
\text { N. Dak. }\end{array}$ & 47.8826 & -98.9677 & 16.3 \\
\hline 9 & 05056000 & $\begin{array}{l}\text { Sheyenne River near Warwick, } \\
\text { N. Dak. }\end{array}$ & 47.8053 & -98.7165 & 2,080 \\
\hline 10 & 05056100 & $\begin{array}{l}\text { Mauvais Coulee near Cando, } \\
\text { N. Dak. }\end{array}$ & 48.4480 & -99.1026 & 398 \\
\hline 11 & 05056200 & $\begin{array}{l}\text { Edmore Coulee near Edmore, } \\
\text { N. Dak. }\end{array}$ & 48.3363 & -98.6605 & 303 \\
\hline 12 & 05056239 & $\begin{array}{l}\text { Starkweather Coulee near } \\
\text { Webster, N. Dak. }\end{array}$ & 48.3204 & -98.9405 & 265 \\
\hline 17 & 05059600 & Maple River near Hope, N. Dak. & 47.3255 & -97.7895 & 20.5 \\
\hline 18 & 05059700 & $\begin{array}{l}\text { Maple River near Enderlin, } \\
\text { N. Dak. }\end{array}$ & 46.6217 & -97.5740 & 832 \\
\hline 19 & 05060000 & $\begin{array}{l}\text { Maple River near Mapleton, } \\
\text { N. Dak. }\end{array}$ & 46.8667 & -97.1058 & 1,466 \\
\hline 20 & 05060100 & $\begin{array}{l}\text { Maple River below Mapleton, } \\
\text { N. Dak. }\end{array}$ & 46.9053 & -97.0526 & 1,473 \\
\hline 21 & 05060500 & Rush River at Amenia, N. Dak. & 47.0153 & -97.2139 & 99.6 \\
\hline 22 & 05062200 & Elm River near Kelso, N. Dak. & 47.2907 & -97.1128 & 173 \\
\hline 23 & 05064900 & $\begin{array}{l}\text { Beaver Creek near Finley, } \\
\text { N. Dak. }\end{array}$ & 47.5947 & -97.7092 & 152 \\
\hline 24 & 05066500 & $\begin{array}{l}\text { Goose River at Hillsboro, } \\
\text { N. Dak. }\end{array}$ & 47.4094 & -97.0612 & 1,217 \\
\hline 25 & 05067500 & Marsh River near Shelly, Minn. & 47.4120 & -96.7632 & 233 \\
\hline
\end{tabular}


Table 1. Hydrologic and basin characteristics for streamgages used.—Continued

[Data from Williams-Sether (2015) unless otherwise noted. N. Dak., North Dakota; S. Dak., South Dakota; Minn., Minnesota; Mont., Montana; no., number]

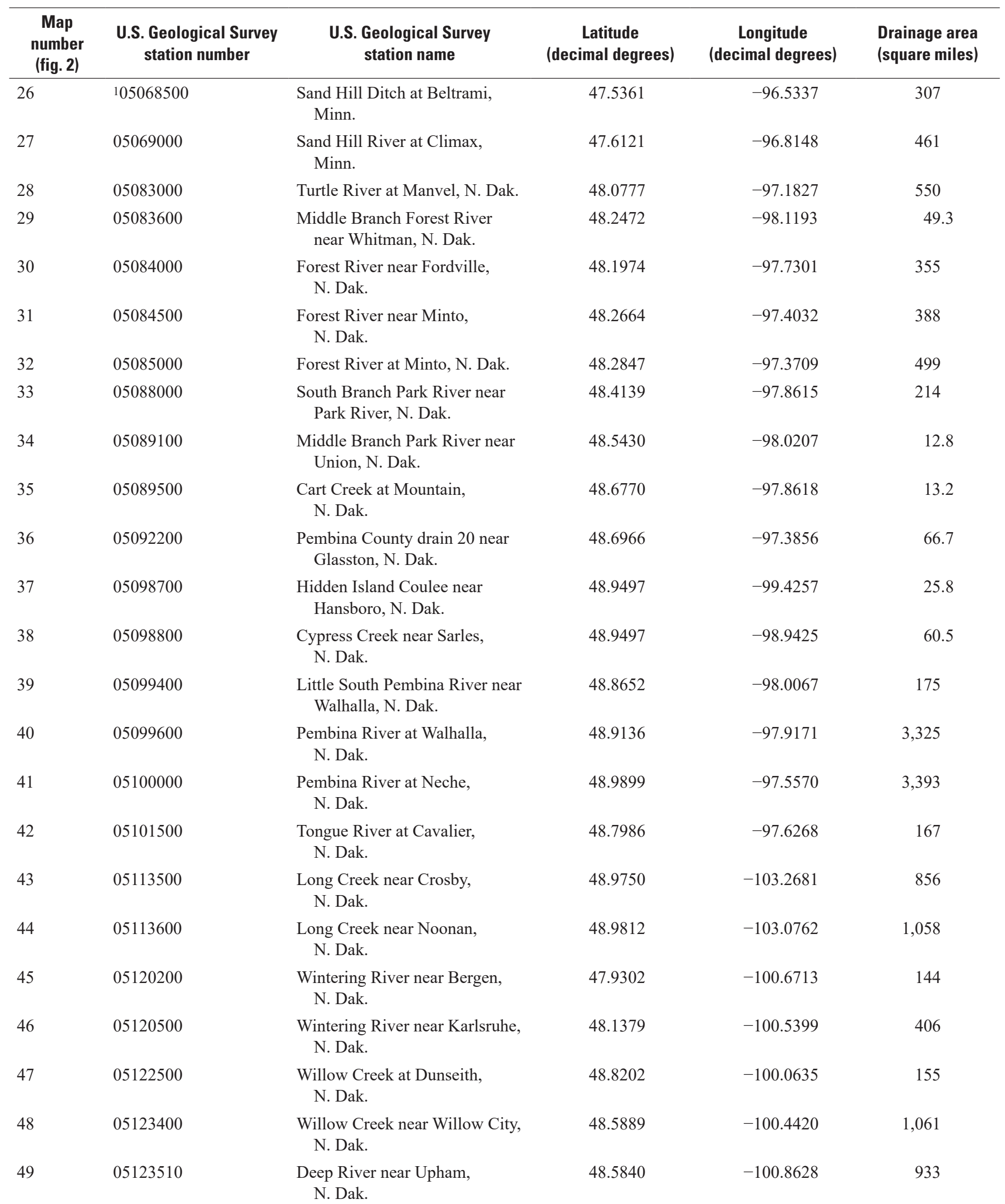


Table 1. Hydrologic and basin characteristics for streamgages used.—Continued

[Data from Williams-Sether (2015) unless otherwise noted. N. Dak., North Dakota; S. Dak., South Dakota; Minn., Minnesota; Mont., Montana; no., number]

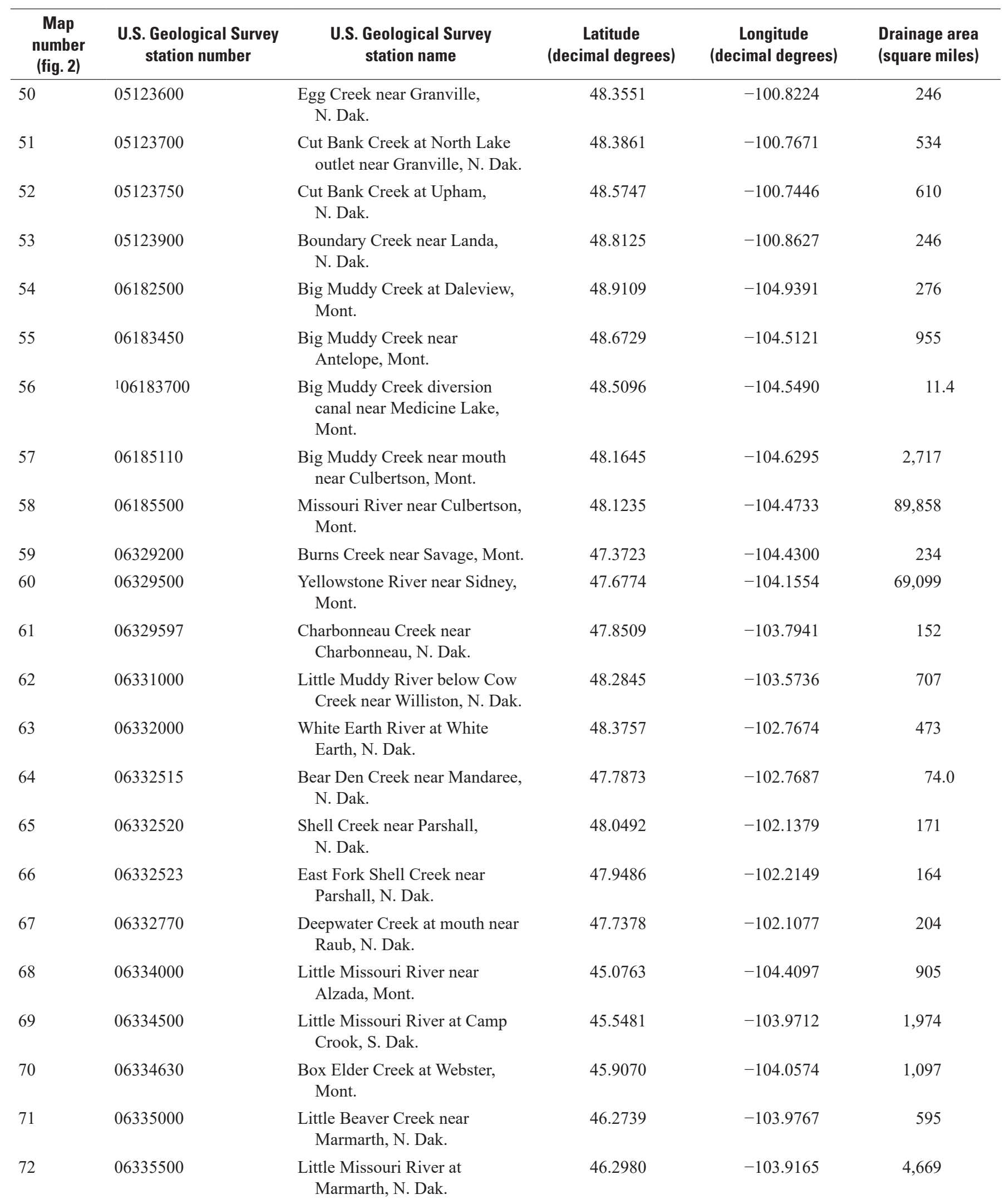


Table 1. Hydrologic and basin characteristics for streamgages used.-Continued

[Data from Williams-Sether (2015) unless otherwise noted. N. Dak., North Dakota; S. Dak., South Dakota; Minn., Minnesota; Mont., Montana; no., number]

\begin{tabular}{|c|c|c|c|c|c|}
\hline $\begin{array}{c}\text { Map } \\
\text { number } \\
\text { (fig. 2) }\end{array}$ & $\begin{array}{l}\text { U.S. Geological Survey } \\
\text { station number }\end{array}$ & $\begin{array}{l}\text { U.S. Geological Survey } \\
\text { station name }\end{array}$ & $\begin{array}{c}\text { Latitude } \\
\text { (decimal degrees) }\end{array}$ & $\begin{array}{c}\text { Longitude } \\
\text { (decimal degrees) }\end{array}$ & $\begin{array}{l}\text { Drainage area } \\
\text { (square miles) }\end{array}$ \\
\hline 73 & 06336000 & $\begin{array}{l}\text { Little Missouri River at Medora, } \\
\text { N. Dak. }\end{array}$ & 46.9166 & -103.5318 & 6,209 \\
\hline 74 & 06336500 & Beaver Creek at Wibaux, Mont. & 46.9899 & -104.1838 & 376 \\
\hline 75 & 06336600 & $\begin{array}{l}\text { Beaver Creek near Trotters, } \\
\text { N. Dak. }\end{array}$ & 47.1631 & -103.9931 & 602 \\
\hline 76 & 06337000 & $\begin{array}{l}\text { Little Missouri River near } \\
\text { Watford City, N. Dak. }\end{array}$ & 47.5959 & -103.2640 & 8,342 \\
\hline 77 & 06339100 & $\begin{array}{l}\text { Knife River at Manning, } \\
\text { N. Dak. }\end{array}$ & 47.2368 & -102.7707 & 204 \\
\hline 78 & 06339300 & $\begin{array}{l}\text { Knife River at Marshall, } \\
\text { N. Dak. }\end{array}$ & 47.1381 & -102.3350 & 739 \\
\hline 80 & 06339500 & $\begin{array}{l}\text { Knife River near Golden Valley, } \\
\text { N. Dak. }\end{array}$ & 47.1544 & -102.0596 & 1,220 \\
\hline 81 & 06339560 & $\begin{array}{l}\text { Brush Creek near Beulah, } \\
\text { N. Dak. }\end{array}$ & 47.1785 & -101.7851 & 24.4 \\
\hline 82 & 06340000 & Spring Creek at Zap, N. Dak. & 47.2861 & -101.9255 & 554 \\
\hline 83 & 06340200 & $\begin{array}{l}\text { West Branch Otter Creek near } \\
\text { Beulah, N. Dak. }\end{array}$ & 47.1343 & -101.6601 & 25.8 \\
\hline 84 & 06340500 & Knife River at Hazen, N. Dak. & 47.2850 & -101.6225 & 2,254 \\
\hline 85 & 06340520 & $\begin{array}{l}\text { Antelope Creek above Hazen, } \\
\text { N. Dak. }\end{array}$ & 47.3353 & -101.6952 & 47.2 \\
\hline 90 & 06341800 & $\begin{array}{l}\text { Painted Woods Creek near } \\
\text { Wilton, N. Dak. }\end{array}$ & 47.2737 & -100.7917 & 191 \\
\hline 91 & 06342450 & $\begin{array}{l}\text { Burnt Creek near Bismarck, } \\
\text { N. Dak. }\end{array}$ & 46.9150 & -100.8137 & 111 \\
\hline 92 & 06343000 & $\begin{array}{l}\text { Heart River near South Heart, } \\
\text { N. Dak. }\end{array}$ & 46.8652 & -102.9484 & 311 \\
\hline 93 & 06344600 & $\begin{array}{l}\text { Green River near New Hradec, } \\
\text { N. Dak. }\end{array}$ & 47.0269 & -103.0538 & 157 \\
\hline 94 & 06345000 & $\begin{array}{l}\text { Green River near Gladstone, } \\
\text { N. Dak. }\end{array}$ & 46.8958 & -102.6253 & 364 \\
\hline 95 & 06347000 & $\begin{array}{l}\text { Antelope Creek near Carson, } \\
\text { N. Dak. }\end{array}$ & 46.5453 & -101.6454 & 238 \\
\hline 96 & 06347500 & $\begin{array}{l}\text { Big Muddy Creek near Almont, } \\
\text { N. Dak. }\end{array}$ & 46.6941 & -101.4676 & 439 \\
\hline
\end{tabular}


Table 1. Hydrologic and basin characteristics for streamgages used.-Continued

[Data from Williams-Sether (2015) unless otherwise noted. N. Dak., North Dakota; S. Dak., South Dakota; Minn., Minnesota; Mont., Montana; no., number]

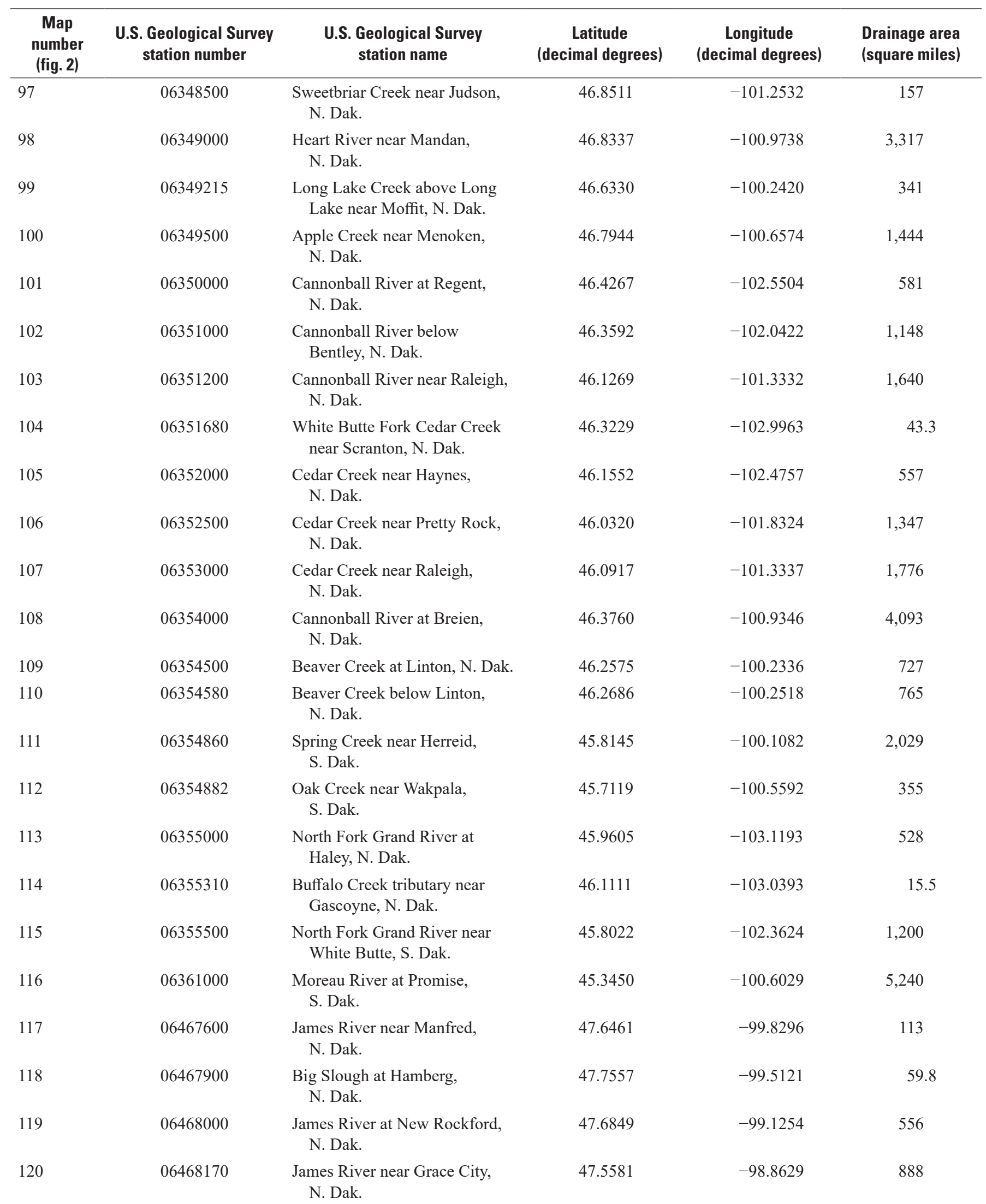


Table 1. Hydrologic and basin characteristics for streamgages used.—Continued

[Data from Williams-Sether (2015) unless otherwise noted. N. Dak., North Dakota; S. Dak., South Dakota; Minn., Minnesota; Mont., Montana; no., number]

\begin{tabular}{|c|c|c|c|c|c|}
\hline $\begin{array}{c}\text { Map } \\
\text { number } \\
\text { (fig. 2) }\end{array}$ & $\begin{array}{l}\text { U.S. Geological Survey } \\
\text { station number }\end{array}$ & $\begin{array}{l}\text { U.S. Geological Survey } \\
\text { station name }\end{array}$ & $\begin{array}{c}\text { Latitude } \\
\text { (decimal degrees) }\end{array}$ & $\begin{array}{c}\text { Longitude } \\
\text { (decimal degrees) }\end{array}$ & $\begin{array}{l}\text { Drainage area } \\
\text { (square miles) }\end{array}$ \\
\hline 121 & 06468250 & $\begin{array}{l}\text { James River above Arrowwood } \\
\text { Lake near Kensal, N. Dak. }\end{array}$ & 47.3993 & -98.7976 & 1,034 \\
\hline 122 & 06468500 & $\begin{array}{l}\text { James River near Pingree, } \\
\text { N. Dak. }\end{array}$ & 47.1417 & -98.7837 & 1,670 \\
\hline 123 & 06469400 & $\begin{array}{l}\text { Pipestem Creek near Pingree, } \\
\text { N. Dak. }\end{array}$ & 47.1673 & -98.9687 & 658 \\
\hline 124 & 06469500 & $\begin{array}{l}\text { Pipestem Creek near Buchanan, } \\
\text { N. Dak. }\end{array}$ & 47.0664 & -98.9190 & 719 \\
\hline 125 & 06470000 & $\begin{array}{l}\text { James River at Jamestown, } \\
\text { N. Dak. }\end{array}$ & 46.8896 & -98.6819 & 2,799 \\
\hline 126 & 06470800 & Bear Creek near Oakes, N. Dak. & 46.2254 & -98.0712 & 417 \\
\hline 127 & 06470833 & Pilot Drain at Oakes, N. Dak. & 46.1249 & -98.0973 & 0.04 \\
\hline 128 & 06471200 & $\begin{array}{l}\text { Maple River at North Dakota- } \\
\text { South Dakota State line }\end{array}$ & 45.9368 & -98.4534 & 480 \\
\hline 129 & 06471500 & Elm River at Westport, S. Dak. & 45.6561 & -98.4970 & 1,505 \\
\hline 130 & 06471800 & $\begin{array}{l}\text { Foot Creek near Aberdeen, } \\
\text { S. Dak. }\end{array}$ & 45.5192 & -98.5775 & 173 \\
\hline 131 & 06472000 & $\begin{array}{l}\text { James River near Stratford, } \\
\text { S. Dak. }\end{array}$ & 45.2416 & -98.3915 & 8,780 \\
\hline
\end{tabular}

${ }^{1}$ Drainage area estimated using respective State StreamStats applications (U.S. Geological Survey, 2018).

ratios. Period of record averages were determined for 30-year normal periods of 1941-70, 1981-2010, and 1987-2016 and the 86-year period of 1931-2016.

Climatic data were modified to account for missing records and nonnumerical data qualifiers. The monthly precipitation and snow depth records, labeled as trace (T), were treated as zeros. Yearly seasonal (November-May) and annual (October-September) precipitation totals were not determined if a missing record was noted within the months of selected periods (November-May and October-September). Yearly seasonal and annual snow depth totals were omitted if a missing record of more than 5 days was noted within the months of selected periods (November-May and October-September). Snow depth totals for June-September were considered to be negligible and treated as zero if labeled as missing. Using climatic data, the expected percentage of snowmelt runoff was calculated for each selected climatic site using a period of record averaged ratio of total snow water equivalent per total precipitation for the selected 30-year normal periods of 1941-70 and 1981-2000 and the 86-year period of 1931-2016.

\section{Map Generation}

All data used in this study were projected, gridded, and mapped using Surfer ${ }^{\circledR} 15$ (Golden Software, 2018). Before generating the annual yield and expected percentage of snowmelt runoff maps, the base maps and datasets were projected to the Albers Equal-Area Conic, in meters. A grid file was then created and used to produce a grid-based map. The grid-based map was created by providing the software program randomly spaced longitudinal coordinate, latitudinal coordinate, and gridded value (annual yield or expected percentage of snowmelt runoff; X, Y, and Z, respectively) data (from the datasets), which were then used to generate a regularly spaced grid file composed of grid nodes. The grid nodes were specific to an $\mathrm{XY}$ location and contained a $\mathrm{Z}$ value.

Golden Software Scripter ${ }^{\mathrm{TM}}$ (Golden Software, 2018) is a program for creating and executing scripts. Instructions are written in a Visual BASIC programming format. Almost everything that can be done manually with a mouse and keyboard in Surfer ${ }^{\circledR} 15$ can be automated through Scripter ${ }^{\mathrm{TM}}$ by scripts (Golden Software, 2018). A script is a text file that contains a series of instructions carried out by a script interpreter program (Scripter ${ }^{\mathrm{TM}}$ ) when the script is run. Scripter ${ }^{\mathrm{TM}}$ was mainly used to automate the repetitive task of generating 


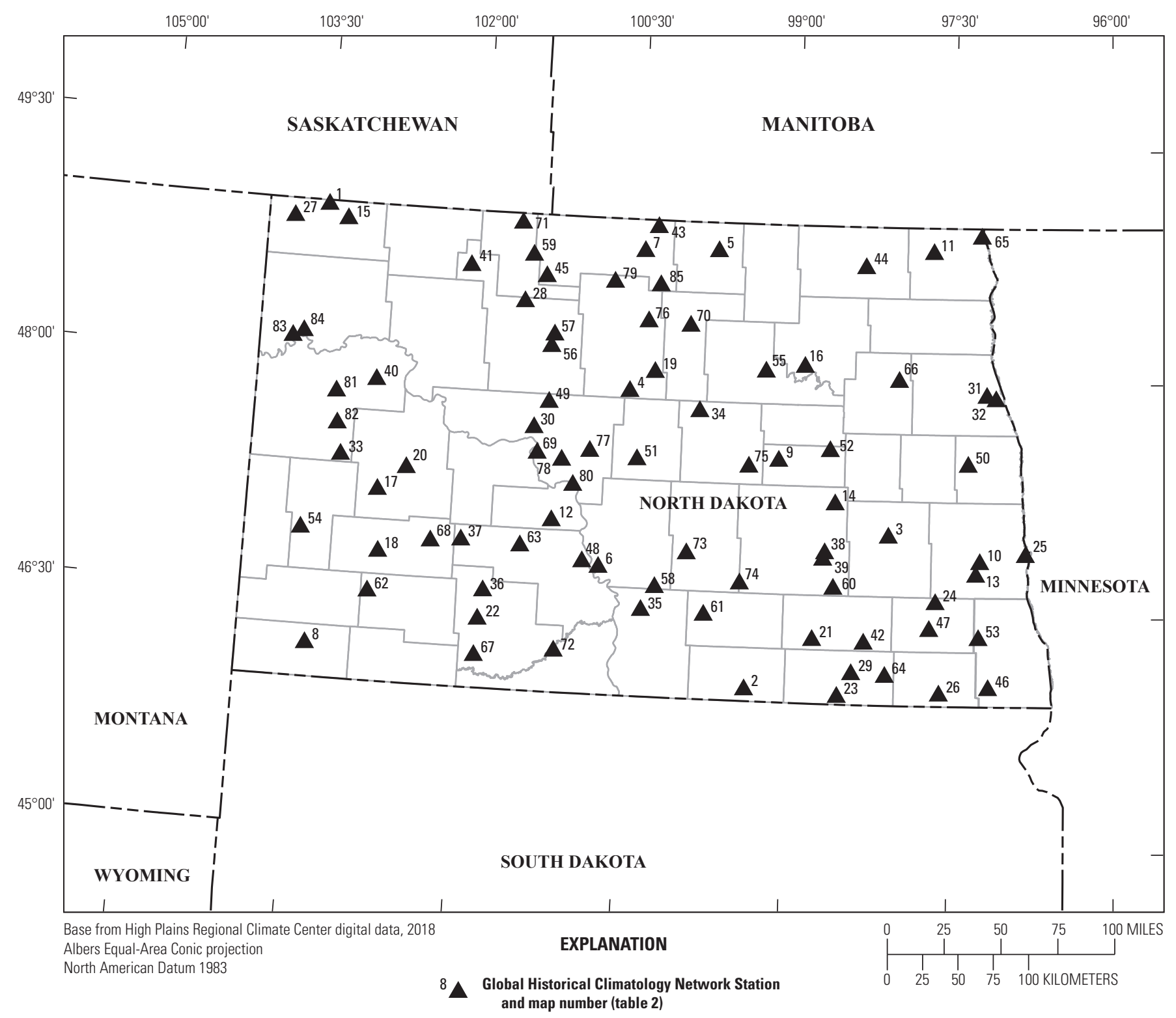

Figure 3. Locations of climatic stations used to estimate alternate expected percentage of snowmelt runoff. 
Table 2. Climatic stations used.

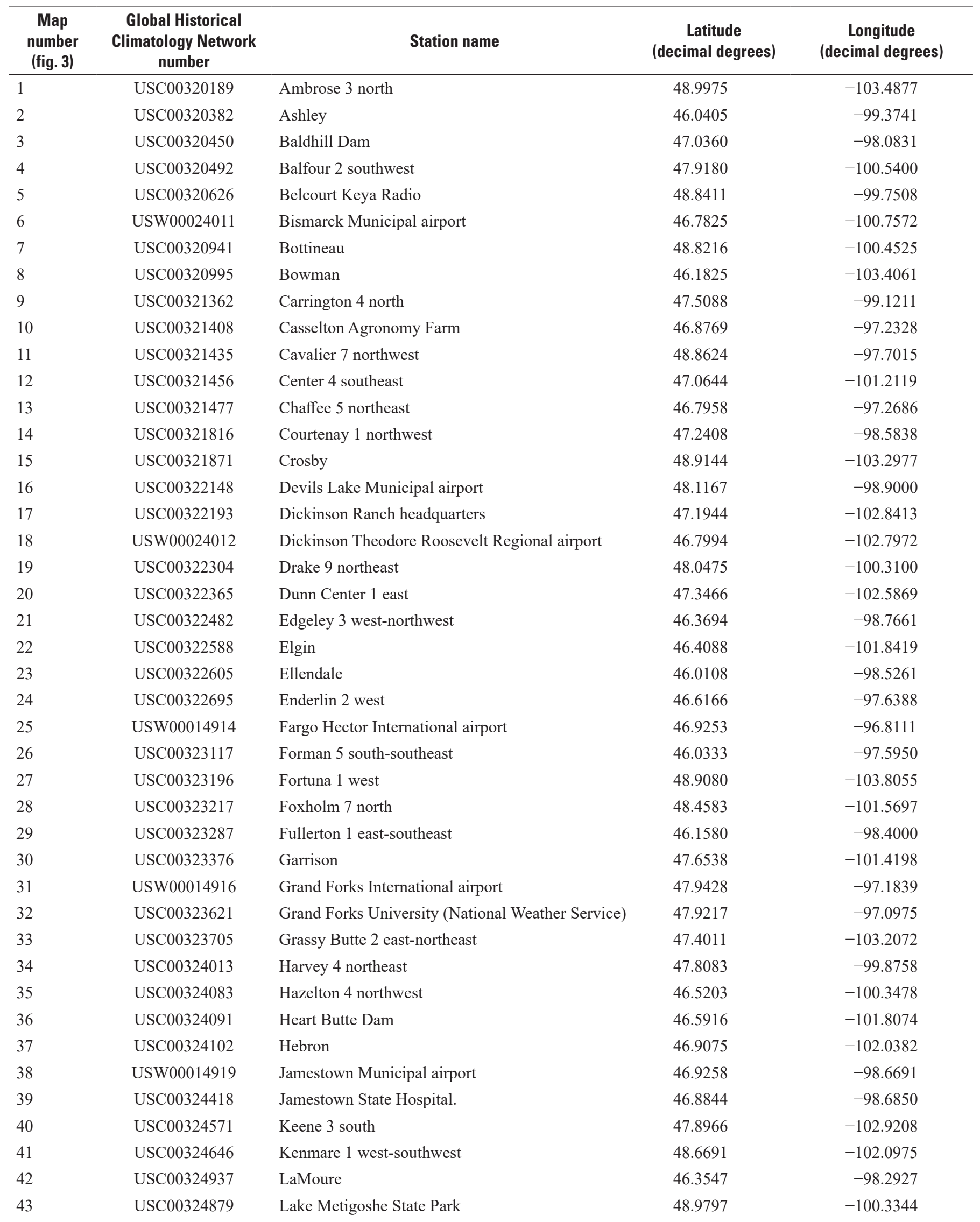


Table 2. Climatic stations used.-Continued

\begin{tabular}{|c|c|c|c|c|}
\hline $\begin{array}{c}\text { Map } \\
\text { number } \\
\text { (fig. 3) }\end{array}$ & $\begin{array}{c}\text { Global Historical } \\
\text { Climatology Network } \\
\text { number }\end{array}$ & Station name & $\begin{array}{c}\text { Latitude } \\
\text { (decimal degrees) }\end{array}$ & $\begin{array}{c}\text { Longitude } \\
\text { (decimal degrees) }\end{array}$ \\
\hline 44 & USC00324958 & Langdon Experiment Farm & 48.7622 & -98.3447 \\
\hline 45 & USC00325002 & Lansford & 48.6272 & -101.3764 \\
\hline 46 & USC00325186 & Lidgerwood & 46.0725 & -97.1461 \\
\hline 47 & USC00325220 & Lisbon & 46.4444 & -97.6928 \\
\hline 48 & USC00325479 & Mandan Experiment Station & 46.8127 & -100.9097 \\
\hline 49 & USC00325638 & $\operatorname{Max}$ & 47.8213 & -101.2922 \\
\hline 50 & USC00325660 & Mayville & 47.4988 & -97.3513 \\
\hline 51 & USC00325710 & McClusky & 47.4825 & -100.4444 \\
\hline 52 & USC00325730 & McHenry & 47.5808 & -98.6422 \\
\hline 53 & USC00325754 & McLeod 3 east & 46.3911 & -97.2391 \\
\hline 54 & USC00325813 & Medora & 46.9161 & -103.5263 \\
\hline 55 & USC00325848 & Minnewaukan & 48.0780 & -99.2655 \\
\hline 56 & USC00325993 & Minot Experiment Station & 48.1802 & -101.2963 \\
\hline 57 & USW00024013 & Minot International airport & 48.2552 & -101.2733 \\
\hline 58 & USC00326015 & Moffit 3 southeast & 46.6705 & -100.2294 \\
\hline 59 & USC00326025 & Mohall & 48.7602 & -101.5090 \\
\hline 60 & USC00326105 & Montpelier & 46.7005 & -98.5839 \\
\hline 61 & USC00326255 & Napoleon & 46.5066 & -99.7691 \\
\hline 62 & USC00326315 & New England & 46.5413 & -102.8691 \\
\hline 63 & USC00326365 & New Salem 5 northwest & 46.8925 & -101.4897 \\
\hline 64 & USC00326620 & Oakes & 46.1458 & -98.0919 \\
\hline 65 & USW00014924 & Pembina & 48.9663 & -97.2476 \\
\hline 66 & USC00327027 & Petersburg 2 north & 48.0356 & -98.0096 \\
\hline 67 & USC00327311 & Pretty Rock & 46.1758 & -101.8561 \\
\hline 68 & USC00327530 & Richardton Abbey & 46.8886 & -102.3191 \\
\hline 69 & USC00327585 & Riverdale & 47.4914 & -101.3775 \\
\hline 70 & USC00327704 & Rugby & 48.3541 & -99.9925 \\
\hline 71 & USC00328047 & Sherwood & 48.9623 & -101.6310 \\
\hline 72 & USC00328065 & Shields & 46.2330 & -101.1291 \\
\hline 73 & USC00328366 & Steele 4 north & 46.8948 & -99.9482 \\
\hline 74 & USC00328415 & Streeter 5 northwest & 46.7154 & -99.4475 \\
\hline 75 & USC00328608 & Sykeston & 47.4647 & -99.3983 \\
\hline 76 & USC00328792 & Towner 2 northeast & 48.3706 & -100.3907 \\
\hline 77 & USC00328840 & Turtle Lake & 47.5213 & -100.8883 \\
\hline 78 & USC00328872 & Underwood & 47.4550 & -101.1461 \\
\hline 79 & USC00328913 & Upham 3 north & 48.6147 & -100.7263 \\
\hline 80 & USC00329195 & Washburn & 47.2981 & -101.0300 \\
\hline 81 & USC00329233 & Watford City & 47.8038 & -103.2891 \\
\hline 82 & USC00329246 & Watford City 14 south & 47.6000 & -103.2597 \\
\hline 83 & USC00329430 & Williston Experiment Farm & 48.1375 & -103.7372 \\
\hline 84 & USW00094014 & Williston Sloulin Field International airport & 48.1738 & -103.6366 \\
\hline 85 & USC00329445 & Willow City & 48.6060 & -100.2910 \\
\hline
\end{tabular}


Table 3. Example application of Weibull plotting for U.S. Geological Survey station 05066500 for the 1941-70 period of record.

[The annual streamflow volumes are determined through methods listed in appendix 1 and (or) 2. Annual yield is determined by dividing the annual volumes by drainage area (1,217 square miles). The annual yields are then ranked from largest to smallest values. The Weibull plotting percentage is determined by dividing the rank of annual yield by number of data in period (30) +1 . The interpolated annual yields associated with the 50 - and 80-percent exceedance probabilities are determined by interpolation of associated numbers (highlighted in yellow) in the "Rank of annual yield" and "Weibull plotting percentage" columns. --, no data]

\begin{tabular}{|c|c|c|c|c|c|c|c|}
\hline $\begin{array}{l}\text { Water } \\
\text { year }\end{array}$ & $\begin{array}{c}\text { Annual stream- } \\
\text { flow volume, } \\
\text { in acre-feet }\end{array}$ & $\begin{array}{l}\text { Annual yield, } \\
\text { in acre-feet per } \\
\text { square mile }\end{array}$ & Rank & $\begin{array}{l}\text { Rank of annual } \\
\text { yield from largest } \\
\text { to smallest values, } \\
\text { in acre-feet per } \\
\text { square mile }\end{array}$ & $\begin{array}{l}\text { Weibull plotting } \\
\text { percentage } \\
\text { computed using } \\
\text { equation } 1\end{array}$ & $\begin{array}{c}\text { Percentage } \\
\text { exceedance } \\
\text { probability, } \\
\text { in percent }\end{array}$ & $\begin{array}{c}\text { Interpolated } \\
\text { annual yield, } \\
\text { in acre-feet per } \\
\text { square mile }\end{array}$ \\
\hline 1941 & $37,449.273$ & 30.772 & 1 & 234.681 & 3.226 & -- & -- \\
\hline 1942 & $24,296.487$ & 19.964 & 2 & 110.841 & 6.452 & -- & -- \\
\hline 1943 & $29,642.812$ & 24.357 & 3 & 100.466 & 9.677 & -- & -- \\
\hline 1944 & $9,880.607$ & 8.119 & 4 & 100.188 & 12.903 & -- & -- \\
\hline 1945 & $12,511.323$ & 10.280 & 5 & 96.181 & 16.129 & -- & -- \\
\hline 1946 & $18,349.359$ & 15.078 & 6 & 94.338 & 19.355 & -- & -- \\
\hline 1947 & $37,371.520$ & 30.708 & 7 & 88.359 & 22.581 & -- & -- \\
\hline 1948 & $121,928.324$ & 100.188 & 8 & 59.192 & 25.806 & -- & -- \\
\hline 1949 & $44,944.523$ & 36.931 & 9 & 36.931 & 29.032 & -- & -- \\
\hline 1950 & $285,606.744$ & 234.681 & 10 & 34.262 & 32.258 & -- & -- \\
\hline 1951 & $27,999.284$ & 23.007 & 11 & 30.772 & 35.484 & -- & -- \\
\hline 1952 & $30,536.379$ & 25.092 & 12 & 30.708 & 38.710 & -- & -- \\
\hline 1953 & $20,012.722$ & 16.444 & 13 & 27.284 & 41.935 & -- & -- \\
\hline 1954 & $12,615.853$ & 10.366 & 14 & 25.092 & 45.161 & -- & -- \\
\hline 1955 & $17,524.223$ & 14.400 & 15 & 24.357 & 48.387 & 50 & 24.21 \\
\hline 1956 & $24,259.593$ & 19.934 & 16 & 24.060 & 51.613 & -- & -- \\
\hline 1957 & $7,099.740$ & 5.834 & 17 & 23.007 & 54.839 & -- & -- \\
\hline 1958 & $5,813.440$ & 4.777 & 18 & 19.964 & 58.065 & -- & -- \\
\hline 1959 & $5,244.572$ & 4.309 & 19 & 19.934 & 61.290 & -- & -- \\
\hline 1960 & $33,204.385$ & 27.284 & 20 & 16.444 & 64.516 & -- & -- \\
\hline 1961 & $6,622.708$ & 5.442 & 21 & 15.078 & 67.742 & -- & -- \\
\hline 1962 & $72,036.951$ & 59.192 & 22 & 14.400 & 70.968 & -- & -- \\
\hline 1963 & $12,319.915$ & 10.123 & 23 & 10.366 & 74.194 & -- & -- \\
\hline 1964 & $29,281.419$ & 24.060 & 24 & 10.280 & 77.419 & -- & -- \\
\hline 1965 & $122,267.502$ & 100.466 & 25 & 10.123 & 80.645 & 80 & 10.15 \\
\hline 1966 & $134,894.066$ & 110.841 & 26 & 8.119 & 83.871 & -- & -- \\
\hline 1967 & $107,532.914$ & 88.359 & 27 & 5.834 & 87.097 & -- & -- \\
\hline 1968 & $41,697.018$ & 34.262 & 28 & 5.442 & 90.323 & -- & -- \\
\hline 1969 & $117,052.286$ & 96.181 & 29 & 4.777 & 93.548 & -- & -- \\
\hline 1970 & $114,809.126$ & 94.338 & 30 & 4.309 & 96.774 & -- & -- \\
\hline
\end{tabular}


all the grid files, to confine the grid size and grid nodes to be consistent for each dataset gridded, and to maintain consistency in gridding future datasets.

The optimal gridding method to use for this study was determined by running a premade script provided by Golden Software in Scripter ${ }^{\mathrm{TM}}$ on a dataset to assist in the gridding method decision. The main goal was to choose the grid that seemed to be the most realistic representation of the data that contained smooth contours. The script created a side-byside visual comparison of all 12 available gridding methods. Grids that seemed to be unrealistic or contained sharp-turning contours were discarded. The remaining grids were evaluated by examining the grid residuals to determine which grid had the best fit to the data. This study used the Surfer ${ }^{\circledR} 15$ kriging method with default options to grid streamflow data and the Surfer ${ }^{\circledR} 15$ polynomial regression to grid expected percentage of snowmelt runoff data. The kriging method grids data by assigning each grid node a value based on the known data points neighboring the node. Each data point is weighted by its distance away from the node; the farther away data points are from the node, the less weight those points will have in the estimation of the value for the node. The polynomial regression method grids data to produce a grid that shows large-scale trends and patterns contained within the dataset. This is a preferred method for generating a trend surface analysis and was used to generate the isolines for expected percentage of snowmelt runoff

\section{Annual Yields and Percentage of Snowmelt Runoff}

The main purpose of this study was to determine how the chapter 7 annual yield map and expected percentage of snowmelt runoff isolines were developed for the North Dakota hydrology manual and to update the chapter 7 annual yield maps (fig. 1; Soil Conservation Service, 1974). Maps likely were developed before 1974; therefore, initial attempts were made using data from 1941 to 1970 . Using the climatic data to determine the expected percentage of snowmelt runoff isolines resulted in a gradient that increased from southeast to northwest (fig. 4). In contrast, the expected percentage of snowmelt isoline gradient shown in the original chapter 7 annual yield maps (fig. 1) increases from southwest to northeast.

A subsequent effort was made using streamflow data from the 131 selected streamgages to determine the expected percentage of snowmelt runoff isolines (fig. 5); however, not all 131 streamgages had complete daily streamflow records, so streamgages were removed from the list if more than 10 years of daily streamflow records were missing from the 1941-70 computations. Removing streamgages with more than 10 years of missing record produced a map that more closely resembled the original map shown in figure 1 and increasing isolines from southwest to northeast. Isoline slopes and percentages were not exact fits to the original lines, likely because the exact streamgages and lengths of records used before 1974 were unknown. The expected percentage of snowmelt runoff isoline determined using a November-May period (fig. $5 \mathrm{~A}$ ) showed a flatter slope and a greater percentage of runoff than the original (fig. 1), but the expected percentage of snowmelt runoff isoline determined using a March-May period (fig. 5B) showed steeper line slopes and percentages that were closer to the original (fig. 1).

Because the chapter 7 annual yield maps are mainly used for small drainages, the streamflow dataset used for the expected percentage of snowmelt runoff isoline attempt was reduced to exclude drainage basins larger than 505 square miles $\left(\mathrm{mi}^{2}\right)$. Maps of expected percentage of snowmelt runoff isolines generated after excluding drainage areas larger than $505 \mathrm{mi}^{2}$ (fig. 6) showed a gradient that increased from the southeast to the northwest, opposite of what was shown in figures 1 and 5. This shift in isoline gradient indicates that expected percentage of snowmelt runoff isoline computations are dependent upon (1) the number of streamgages being used, (2) the runoff period being used, (3) the period of record being used, and (4) the number of missing years allowed within the period of record. Examination of the results illustrated in figures 2-6 led to a streamgage dataset with drainage areas of $505 \mathrm{mi}^{2}$ or less for the 1931-2016 period of record and a runoff period of March-May used for the final expected percentage of snowmelt runoff computations.

Initial attempts to duplicate the annual yield for the 50- and 80-percent exceedance probabilities using data from 1941-70 with 10-percent or less missing record and kriging methods to generate the contour lines are shown in figure 7. Although the resulting maps were similar to the original map (with highs and lows in similar places), an exact match was unattainable because the number of sites and record lengths used were unknown. Variability of the contours was dependent upon the number of streamgages being used and the period of record used to calculate exceedance probabilities.

Potential contouring problems may exist in the form of steep gradients (dark zones in fig. 7). The primary cause for the contouring problems likely is the juxtaposition of large and small percentage exceedance probabilities associated with streamgages near each other. However, the variability of recorded data with extreme flow years (low or high) and the variability of the annual flow volumes estimated using streamflow volume record-extension procedures (MOVE.3) also may contribute to contouring problems in figure 7. Closer examination of the contour maps showed steep gradient areas at locations of streamgages with larger drainage basins and those that had more than 50 percent of the period of record annual volumes estimated by MOVE.3. Data used to generate the updated contour maps were restricted to drainage areas of $505 \mathrm{mi}^{2}$ or less and the 1931-2016 period of record with 10-percent or less missing record to be consistent with the expected percentage of snowmelt runoff isoline data.

Updated combined maps of the annual yield contours and expected percentage of snowmelt runoff isolines using data from 1931 to 2016 are shown in figures 8-11. Streamgages 


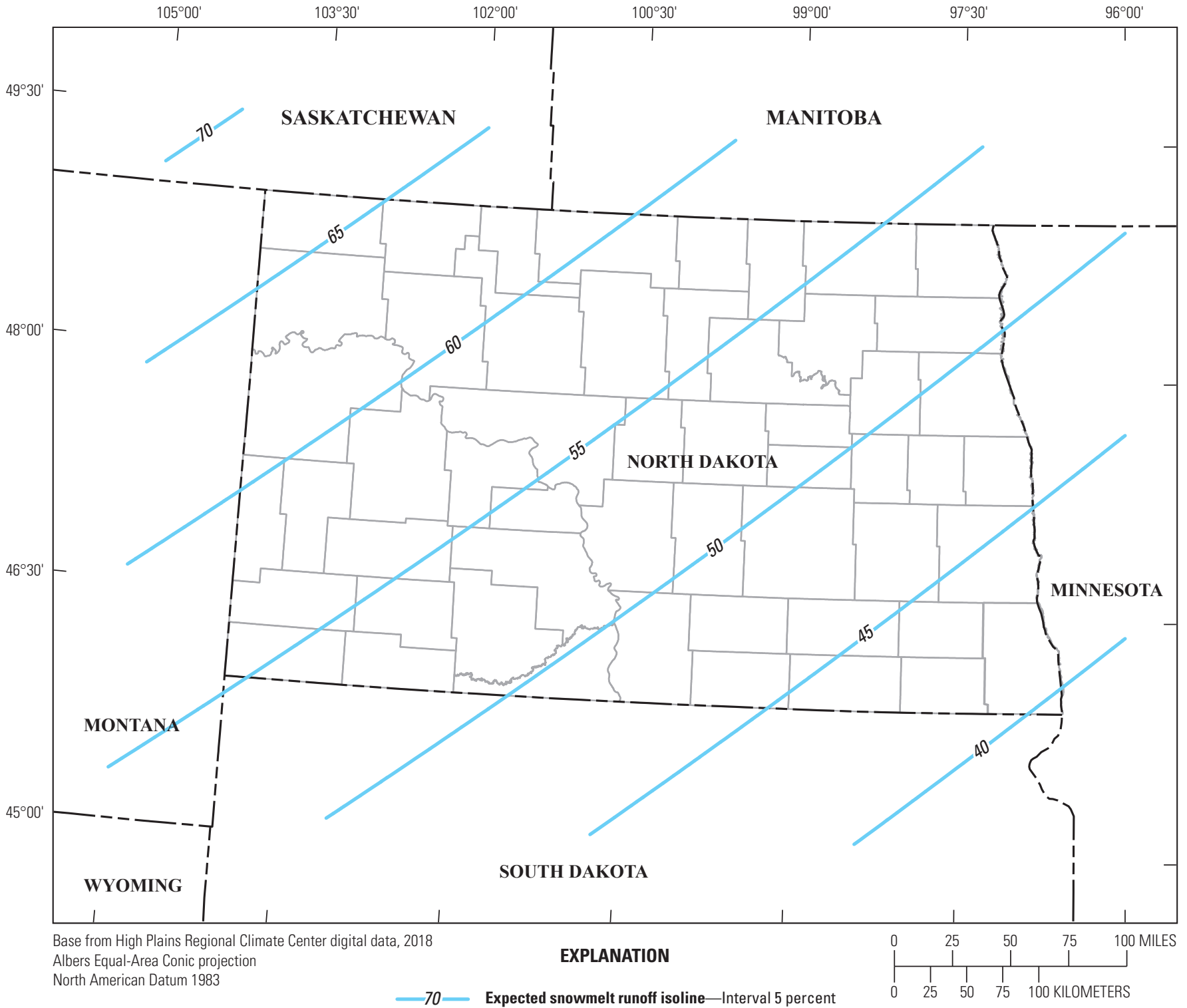

Figure 4. Expected percentage of snowmelt runoff isolines for 1941-70 using November-May climatic data.

with 10-percent or less missing calculated and estimated annual volumes were used to generate figures 8 and 9 because a full 86 -year record length resulted in a sparse dataset. The expected percentage of snowmelt runoff calculations were allowed to be missing a record of 28 years ( 33 percent), 43 years ( 50 percent), and 57 years ( 66 percent) because few streamgages had a complete 86-year record length. Maps generated using different missing data thresholds were then compared to examine the effect of missing streamgages and record on the average expected percentage of snowmelt runoff calculations in terms of isoline slope and percentage. Streamgages that had 10-percent or less missing annual volume record and 50 percent or less of the annual volumes estimated by MOVE. 3 were used to generate figures 10 and 11. Again, the expected percentage of snowmelt runoff calculations were allowed to be missing a record of 28 years ( 33 percent), 43 years ( 50 percent), and 57 years (66 percent). Maps can be compared to illustrate how using streamgages with less estimated annual volume affects generated isolines.

Maps generated using streamgages with 50 percent or less estimated annual volumes from MOVE. 3 indicated less contouring problems of steep gradients caused by large and small percentage exceedance probabilities for streamgages that are near each other. The expected percentage of snowmelt runoff isoline slopes were similar to those of the original chapter 7 annual yield map when 50 percent and 66 percent of the period of record (1931-2016) was allowed to be missing. 


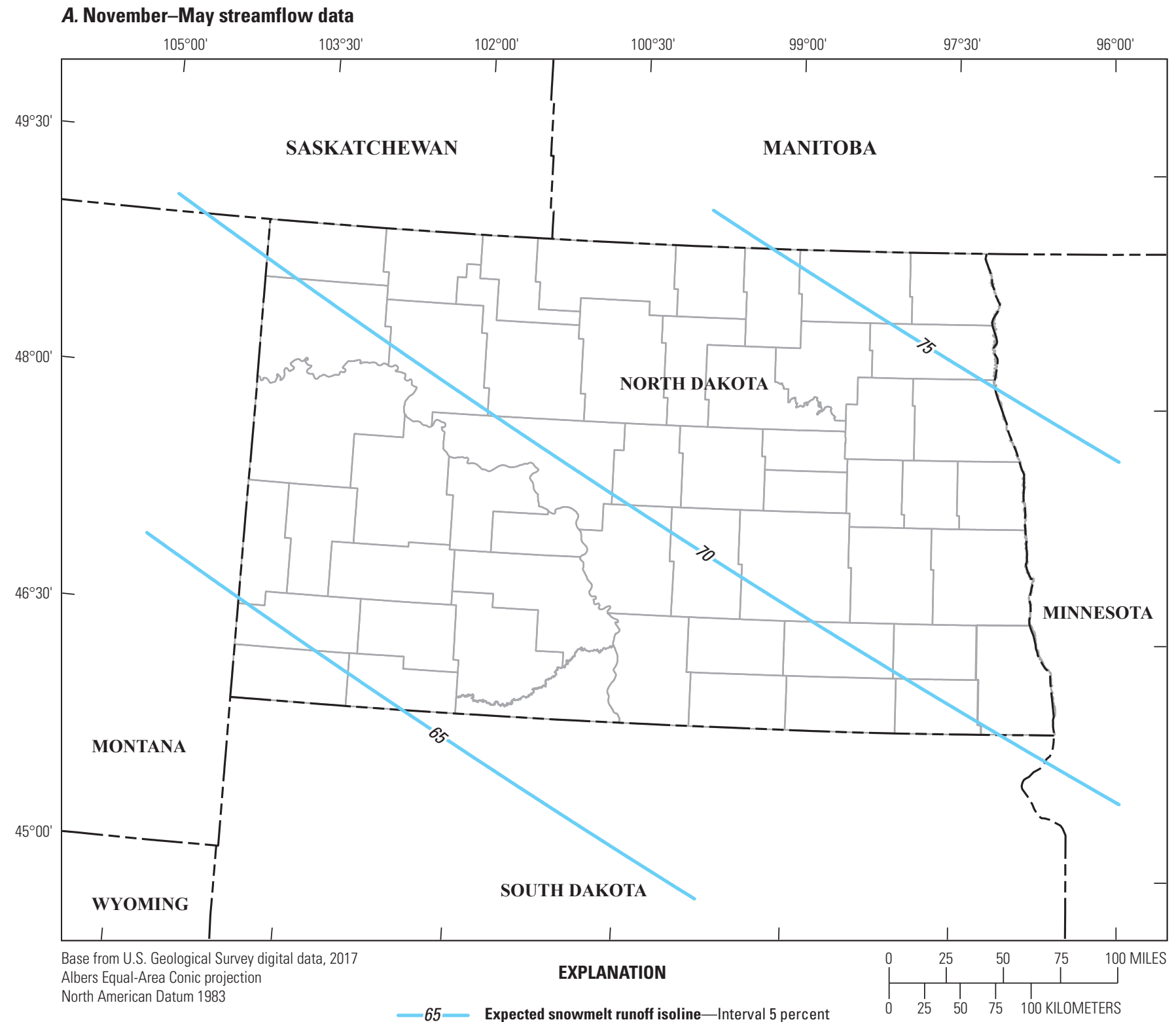

Figure 5. Expected percentage of snowmelt runoff isolines for 1941-70 using streamflow data. A, November-May streamflow data; $B$, March-May streamflow data. 
B. March-May streamflow data

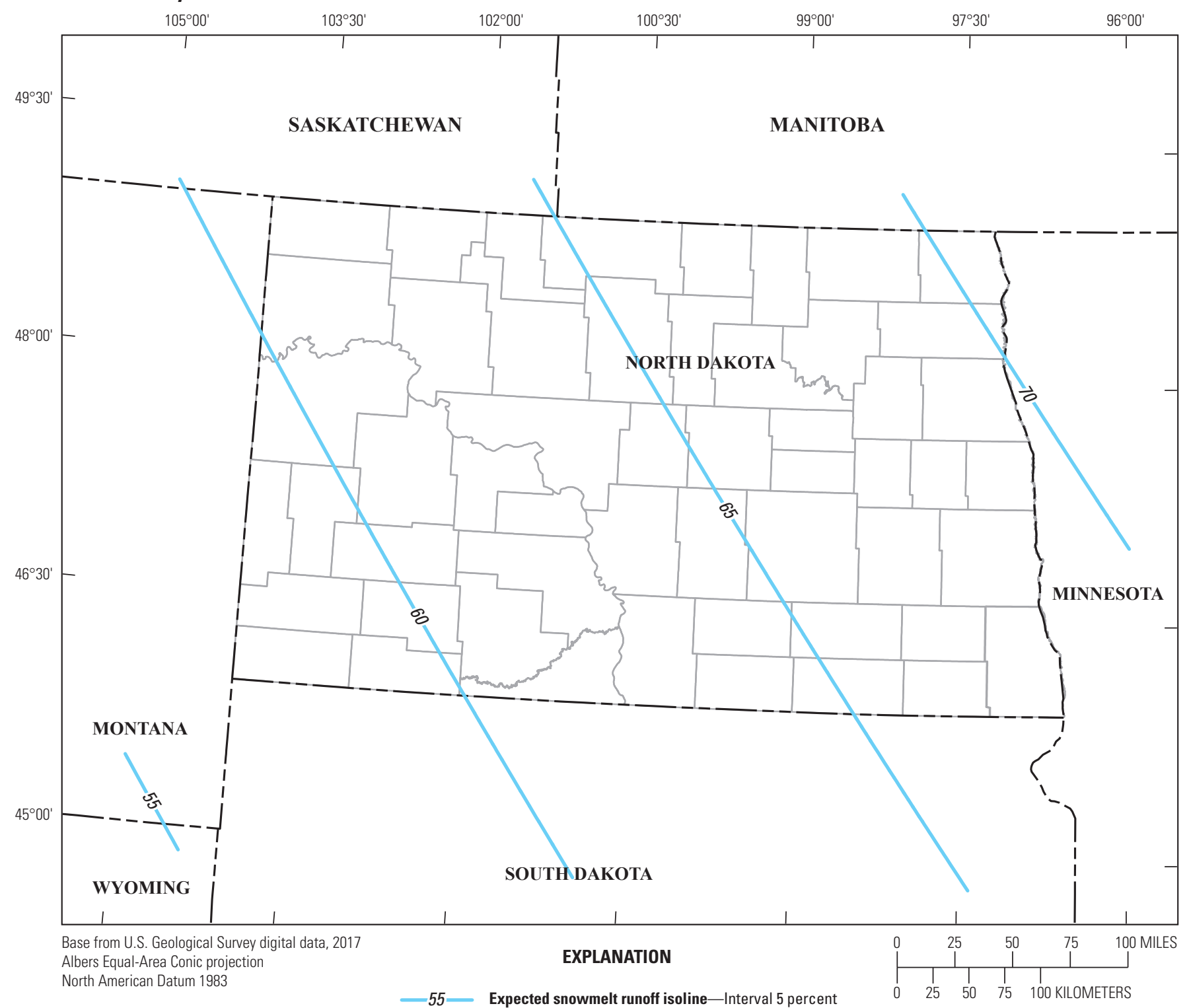

Figure 5. Expected percentage of snowmelt runoff isolines for 1941-70 using streamflow data. A, November-May streamflow data; $B$, March-May streamflow data.-Continued 


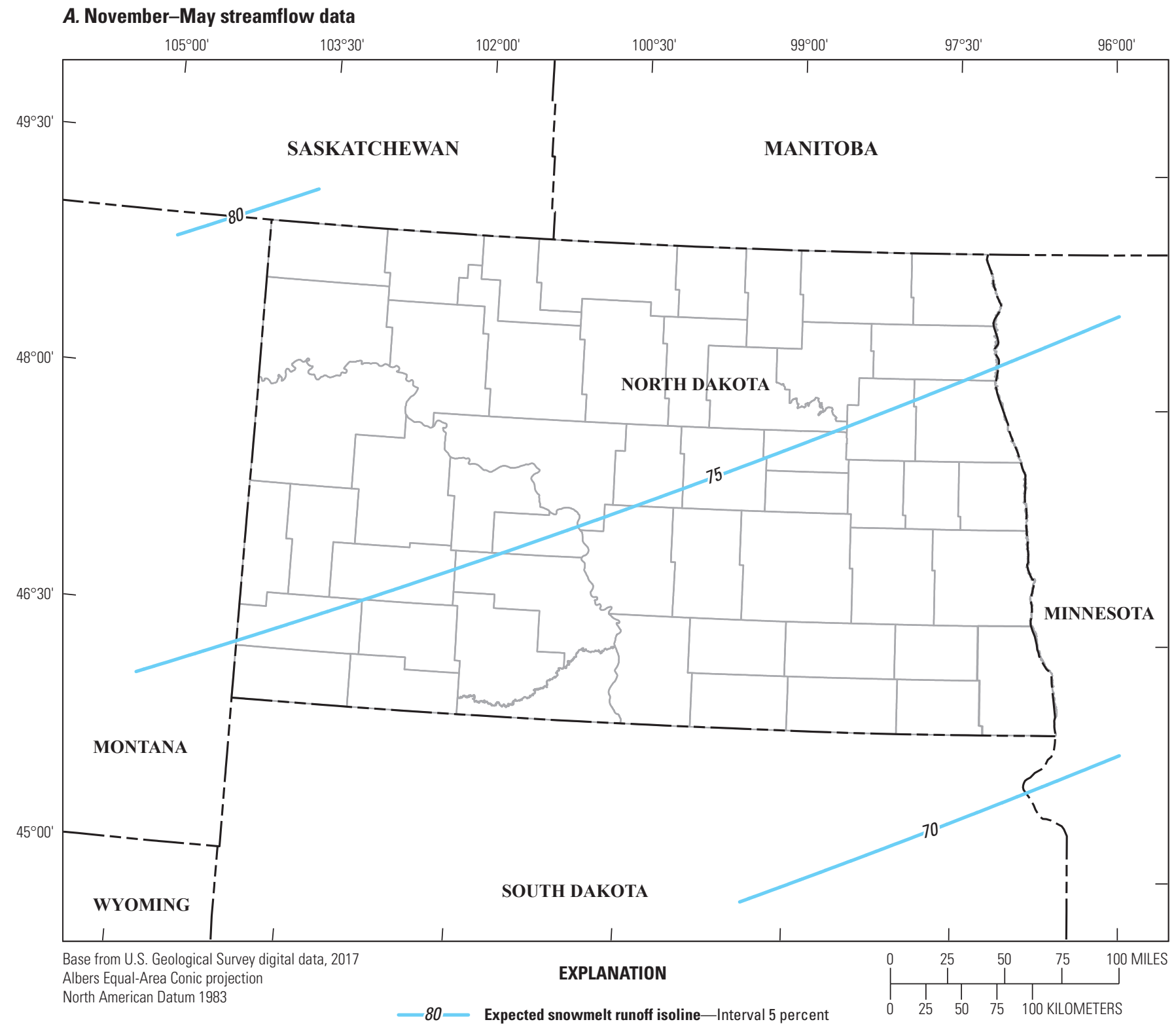

Figure 6. Expected percentage of snowmelt runoff isolines for 1941-70 with drainage areas of 505 square miles or less using streamflow data. $A$, November-May streamflow data; $B$, March-May streamflow data. 
B. March-May streamflow data

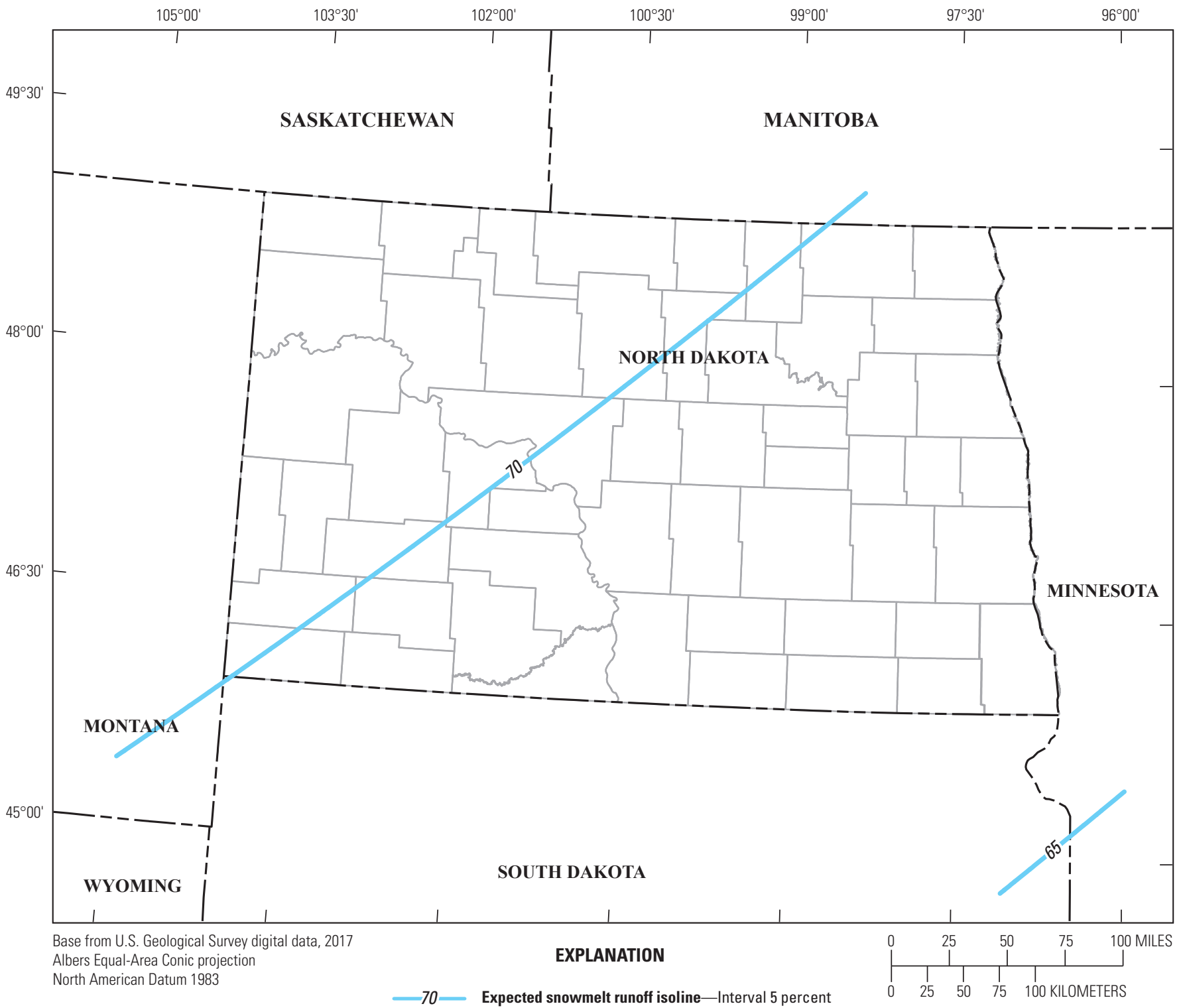

Figure 6. Expected percentage of snowmelt runoff isolines for 1941-70 with drainage areas of 505 square miles or less using streamflow data. $A$, November-May streamflow data; $B$, March-May streamflow data._Continued 
A. 50-percent exceedance probability

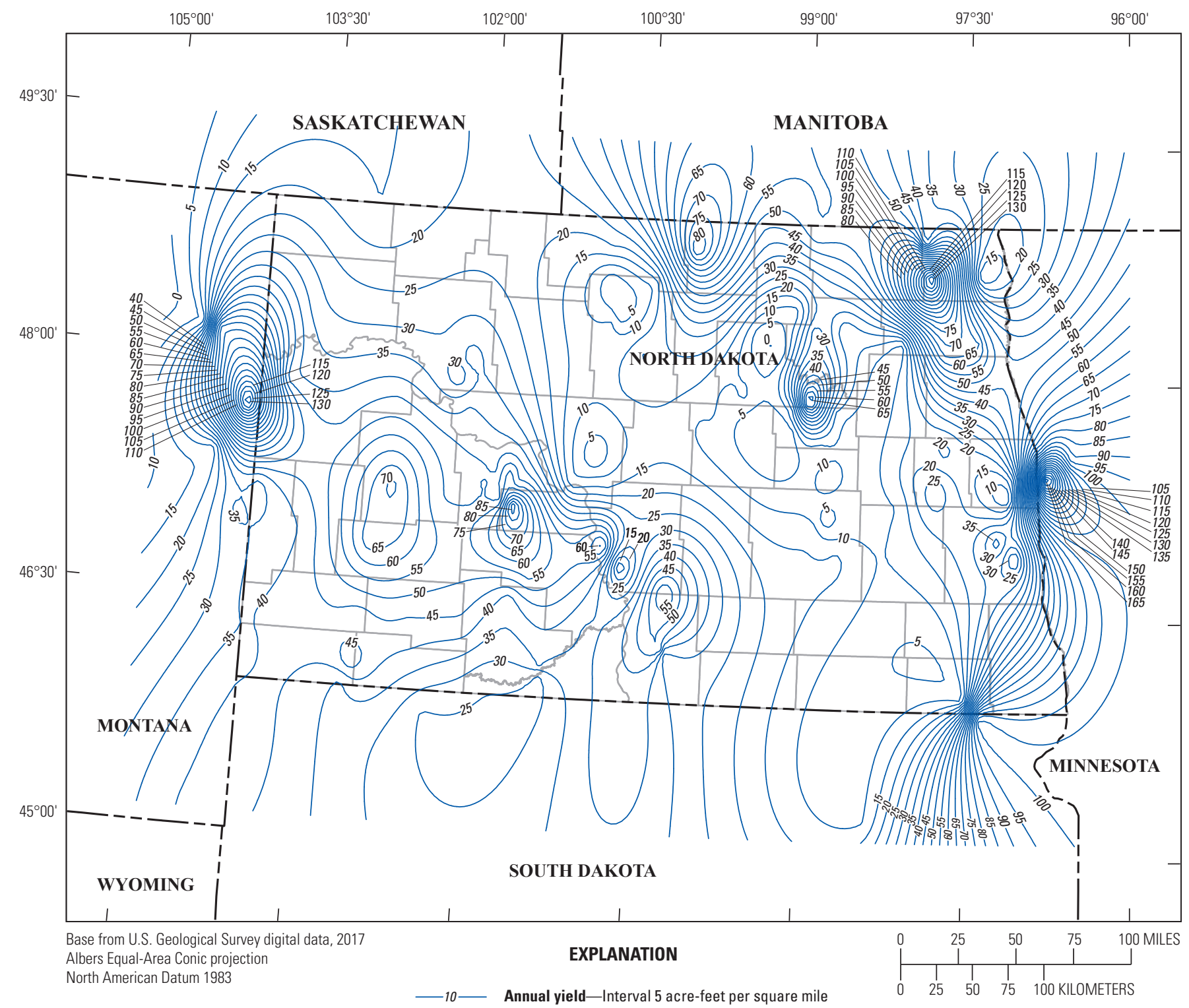

Figure 7. Annual yield using 131 selected streamgages and a period of record of 1941-70 with 10-percent or less missing record. $A$, 50-percent exceedance probability; $B, 80$-percent exceedance probability. 
B. 80-percent exceedance probability

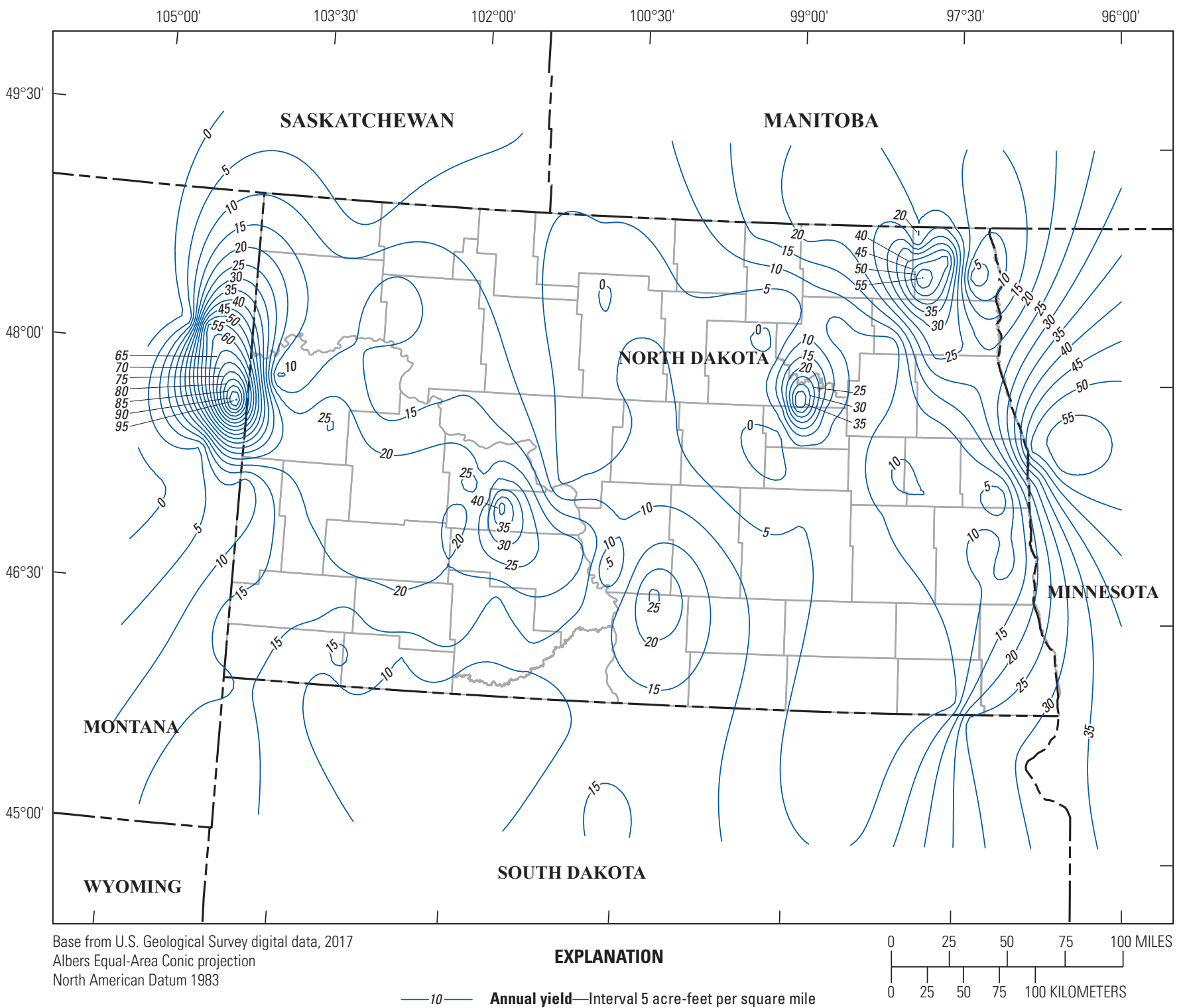

Figure 7. Annual yield using 131 selected streamgages and a period of record of 1941-70 with 10-percent or less missing record. $A$, 50-percent exceedance probability; $B$, 80-percent exceedance probability.-Continued 


\section{A. Missing 33 percent of record}

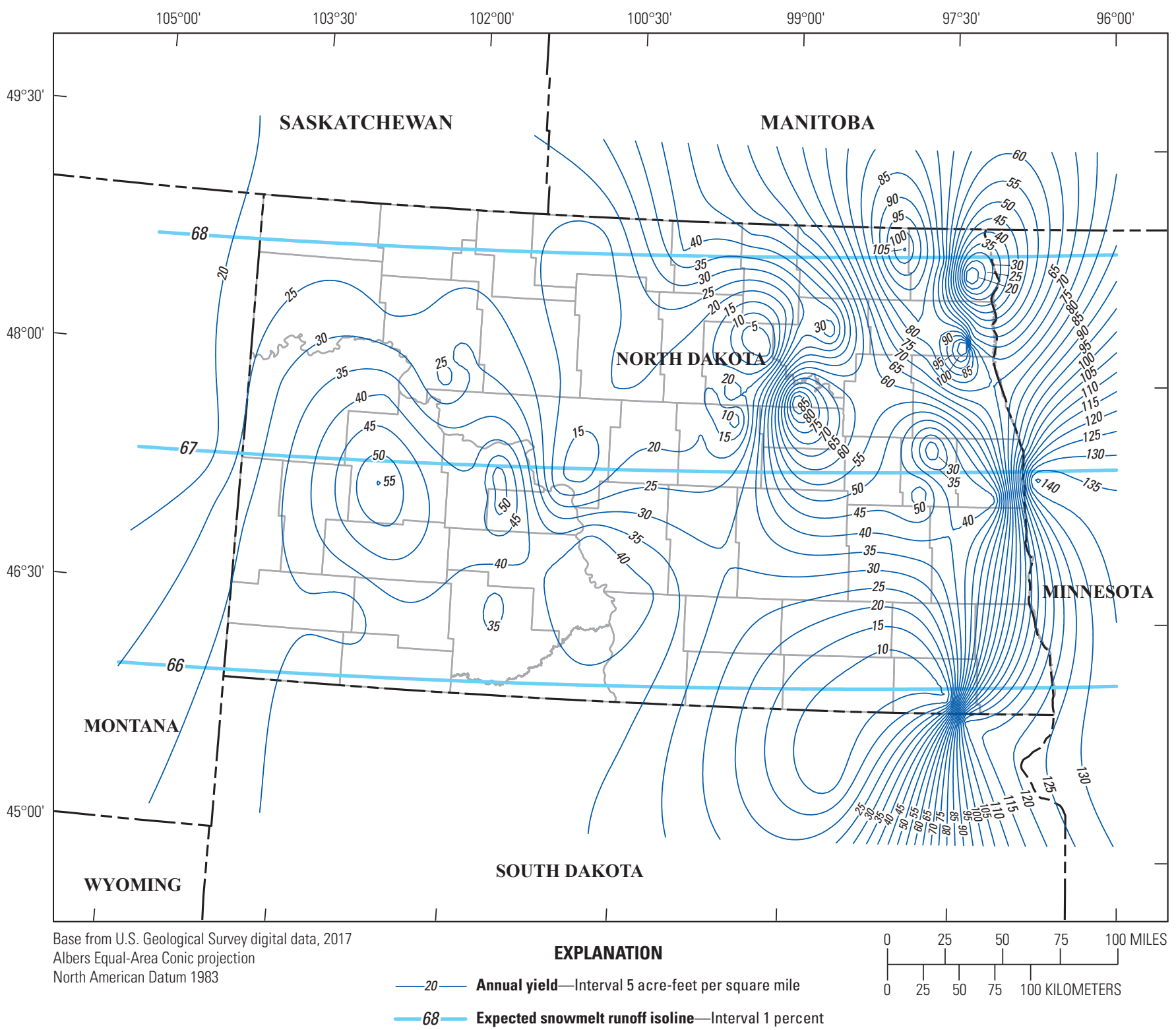

Figure 8. Annual yield at the 50-percent exceedance probability using 1931-2016 data with streamgages that have 10-percent or less missing calculated and estimated annual volumes and a drainage area of 505 square miles or less and allowing the 1931-2016 data to have a missing record for expected percentage of snowmelt runoff. $A$, missing 33 percent of record; $B$, missing 50 percent of record; $C$, missing 66 percent of record. 


\section{$B$. Missing 50 percent of record}

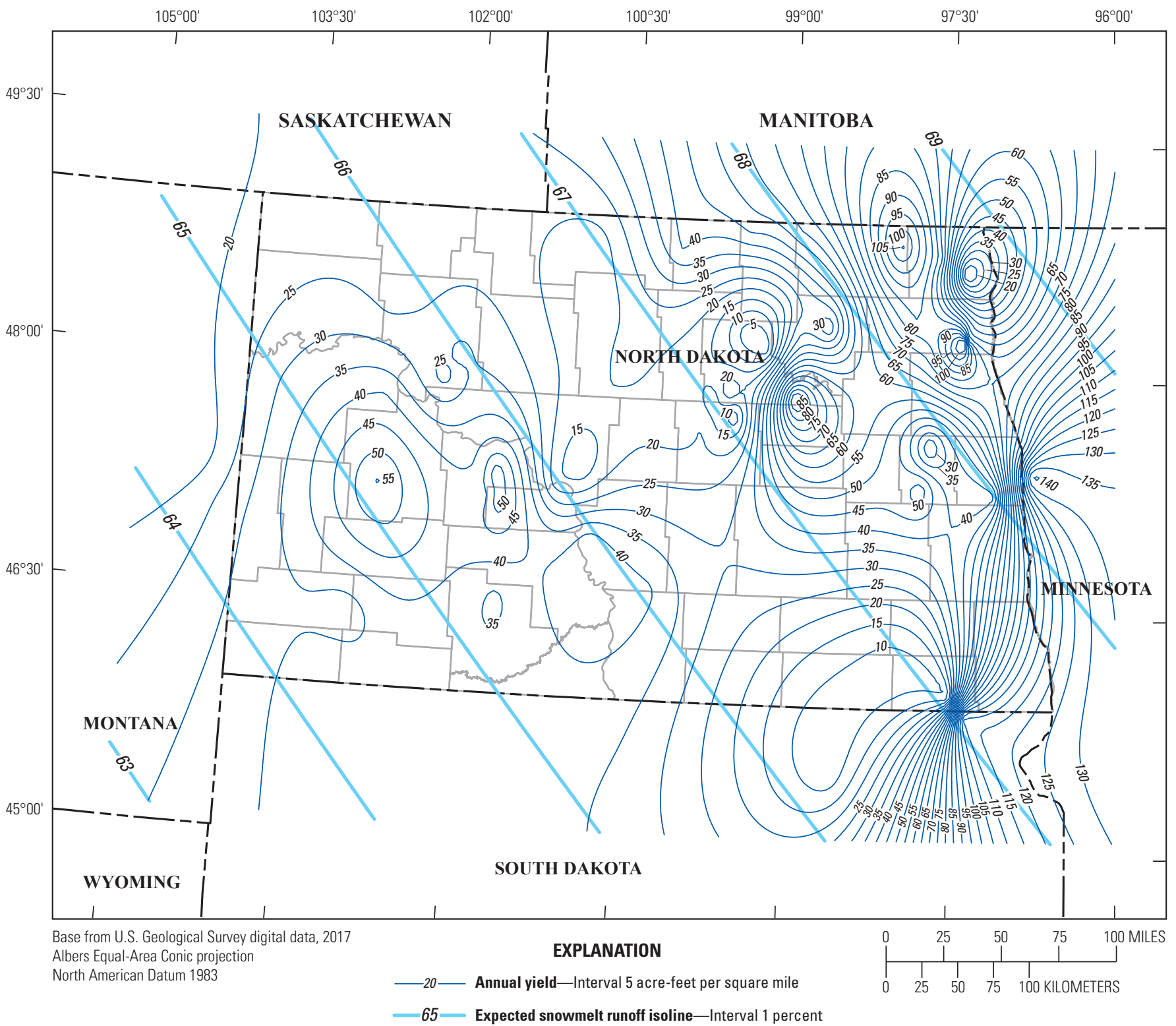

Figure 8. Annual yield at the 50-percent exceedance probability using 1931-2016 data with streamgages that have 10-percent or less missing calculated and estimated annual volumes and a drainage area of 505 square miles or less and allowing the 1931-2016 data to have a missing record for expected percentage of snowmelt runoff. $A$, missing 33 percent of record; $B$, missing 50 percent of record; $C$, missing 66 percent of record.-Continued 


\section{Missing 66 percent of record}

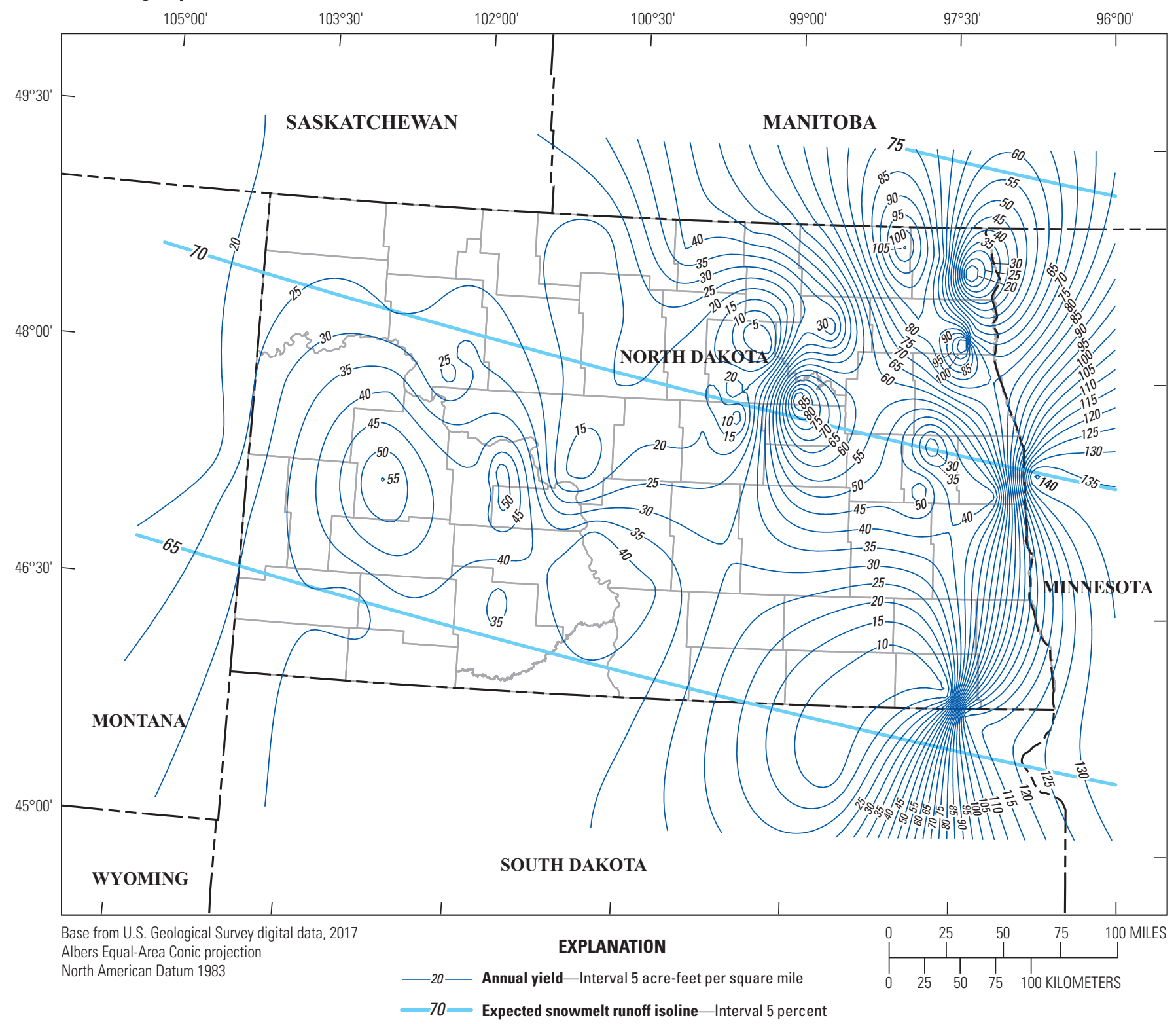

Figure 8. Annual yield at the 50-percent exceedance probability using 1931-2016 data with streamgages that have 10-percent or less missing calculated and estimated annual volumes and a drainage area of 505 square miles or less and allowing the 1931-2016 data to have a missing record for expected percentage of snowmelt runoff. $A$, missing 33 percent of record; $B$, missing 50 percent of record; $C$, missing 66 percent of record.-Continued 
A. Missing 33 percent of record

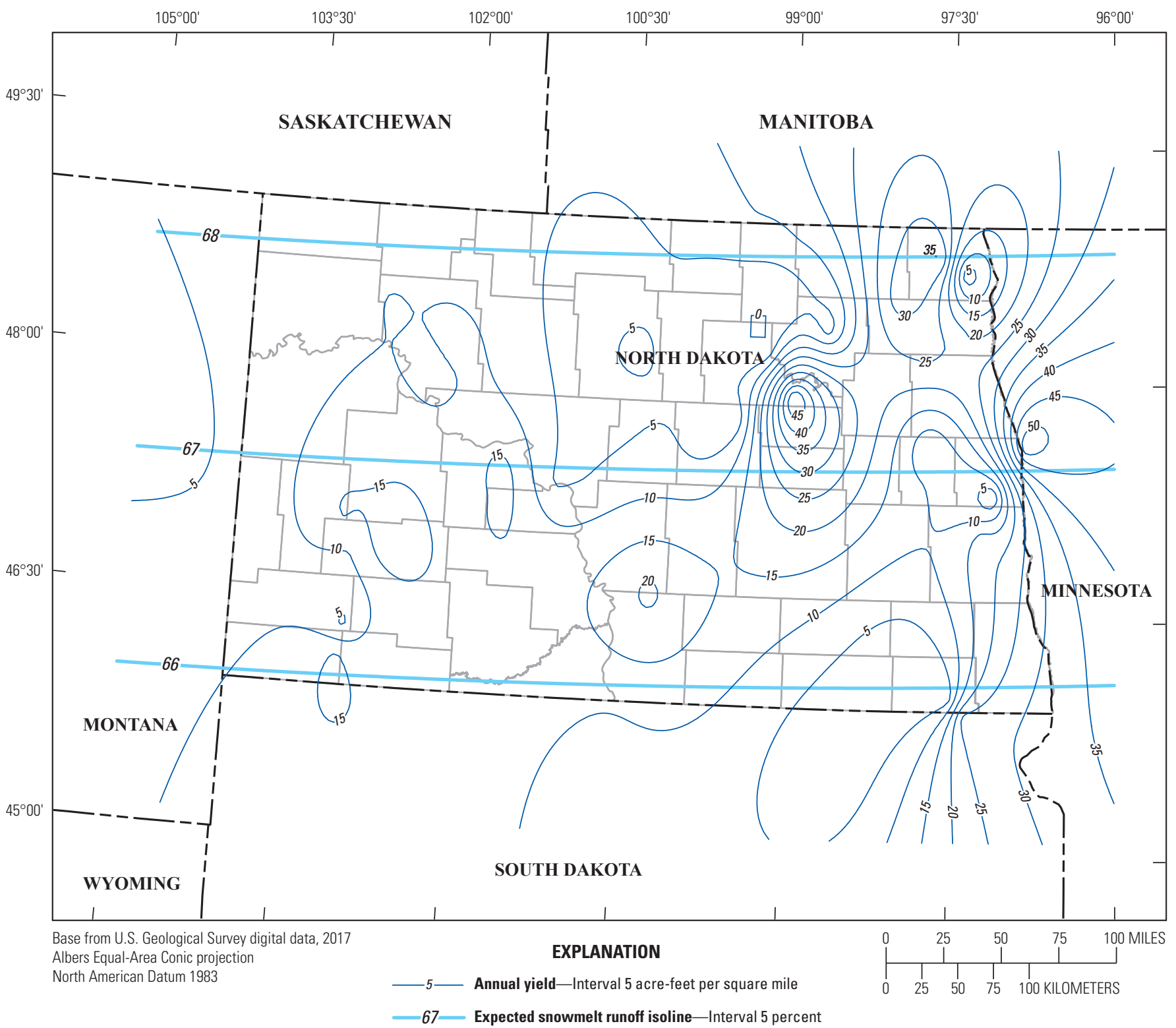

Figure 9. Annual yield at the 80-percent exceedance probability using 1931-2016 data with streamgages that have 10-percent or less missing calculated and estimated annual volumes and a drainage area of 505 square miles or less and allowing the 1931-2016 data to have a missing record for expected percentage of snowmelt runoff. $A$, missing 33 percent of record; $B$, missing 50 percent of record; $C$, missing 66 percent of record. 


\section{B. Missing 50 percent of record}

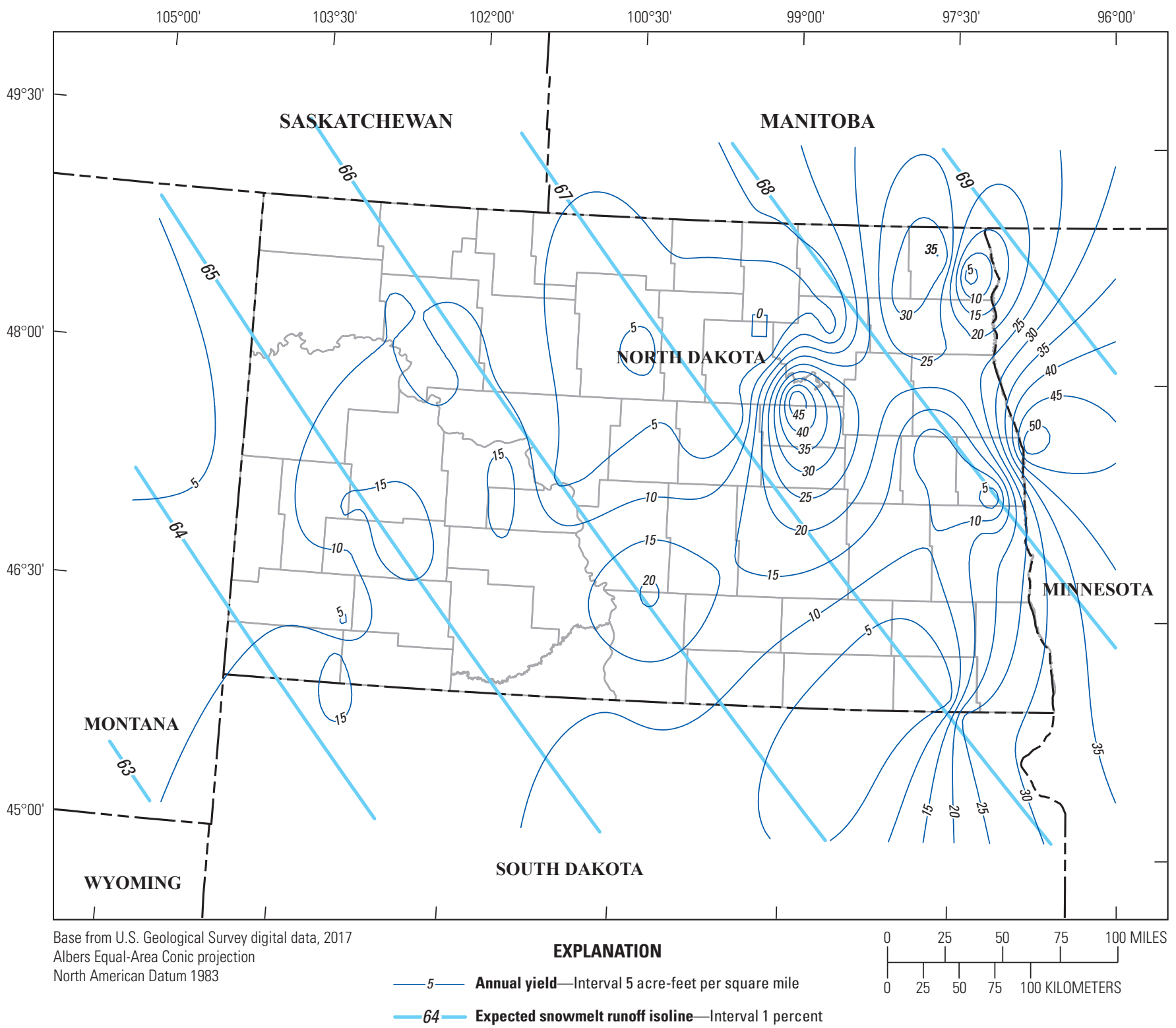

Figure 9. Annual yield at the 80-percent exceedance probability using 1931-2016 data with streamgages that have 10-percent or less missing calculated and estimated annual volumes and a drainage area of 505 square miles or less and allowing the 1931-2016 data to have a missing record for expected percentage of snowmelt runoff. $A$, missing 33 percent of record; $B$, missing 50 percent of record; $C$, missing 66 percent of record.-Continued 


\section{Missing 66 percent of record}

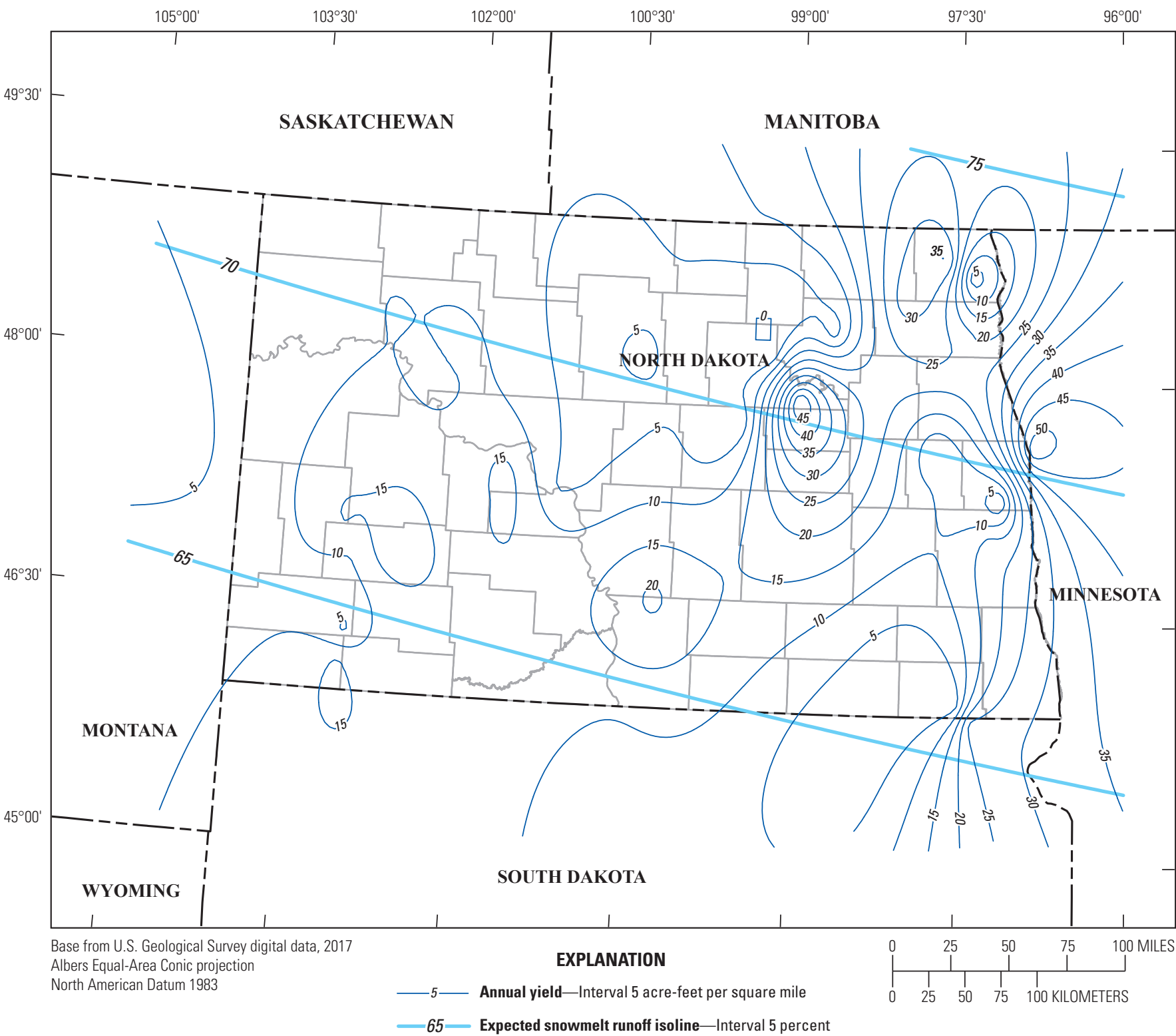

Figure 9. Annual yield at the 80-percent exceedance probability using 1931-2016 data with streamgages that have 10-percent or less missing calculated and estimated annual volumes and a drainage area of 505 square miles or less and allowing the 1931-2016 data to have a missing record for expected percentage of snowmelt runoff. $A$, missing 33 percent of record; $B$, missing 50 percent of record; $C$, missing 66 percent of record.-Continued 


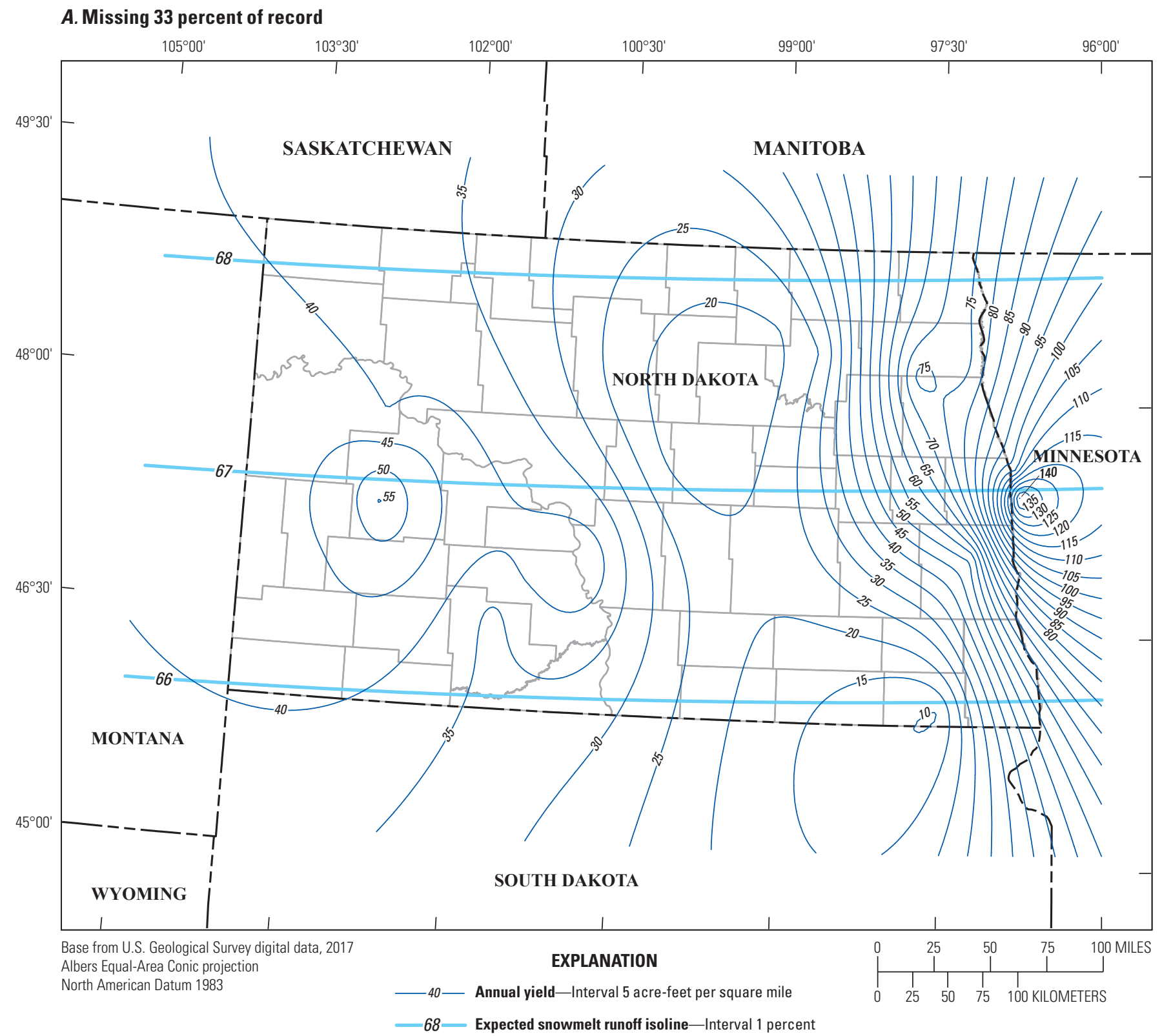

Figure 10. Annual yield at the 50-percent exceedance probability using 1931-2016 data with streamgages that have 10-percent or less missing annual volume record and 50 percent or less of Maintenance of Variance Extension Type III annual volume estimations and a drainage area of 505 square miles or less and allowing the 1931-2016 data to have a missing record for expected percentage of snowmelt runoff. $A$, missing 33 percent of record; $B$, missing 50 percent of record; $C$, missing 66 percent of record. 


\section{B. Missing $\mathbf{5 0}$ percent of record}

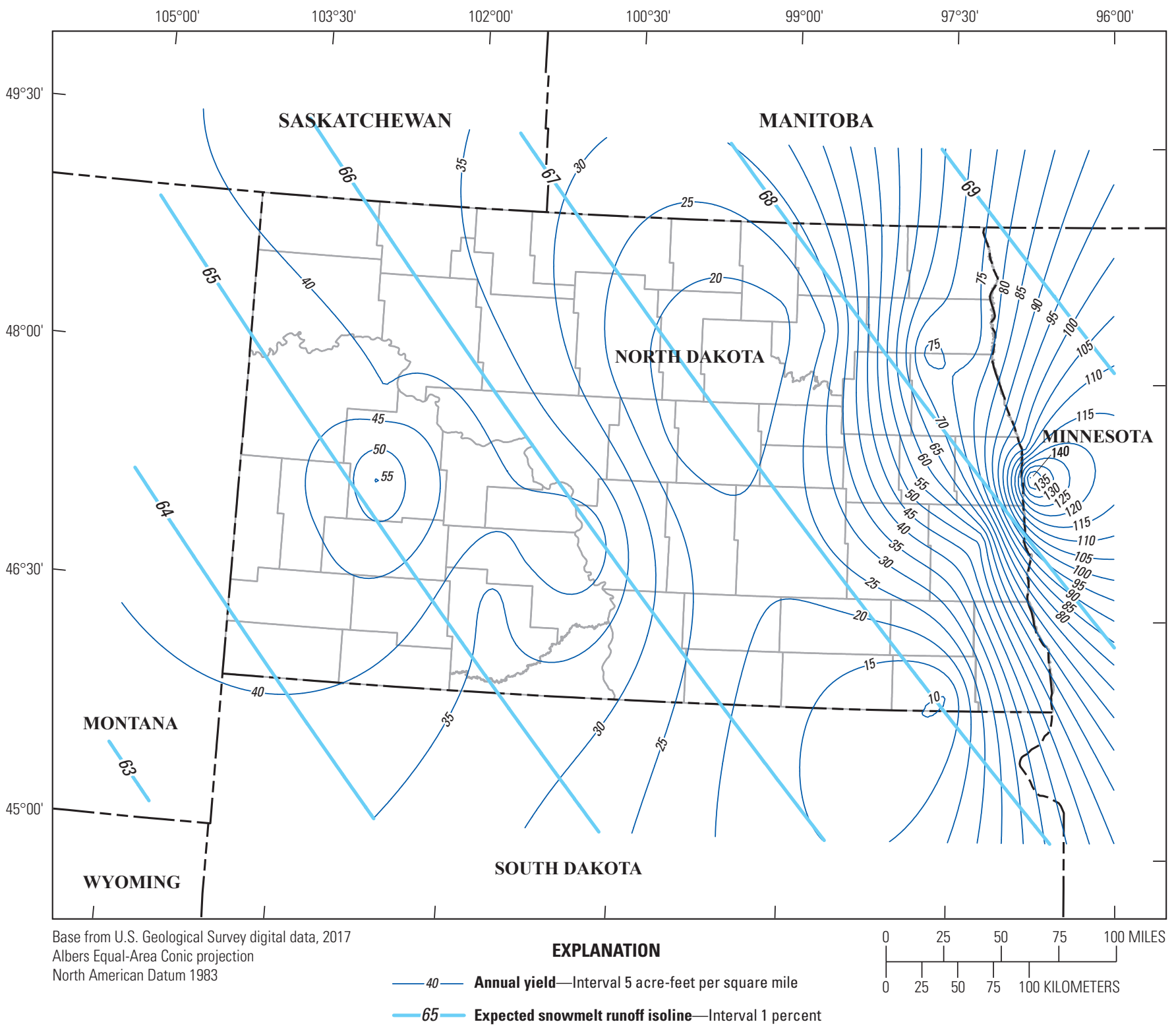

Figure 10. Annual yield at the 50-percent exceedance probability using 1931-2016 data with streamgages that have 10-percent or less missing annual volume record and 50 percent or less of Maintenance of Variance Extension Type III annual volume estimations and a drainage area of 505 square miles or less and allowing the 1931-2016 data to have a missing record for expected percentage of snowmelt runoff. $A$, missing 33 percent of record; $B$, missing 50 percent of record; $C$, missing 66 percent of record.-Continued 


\section{Missing 66 percent of record}

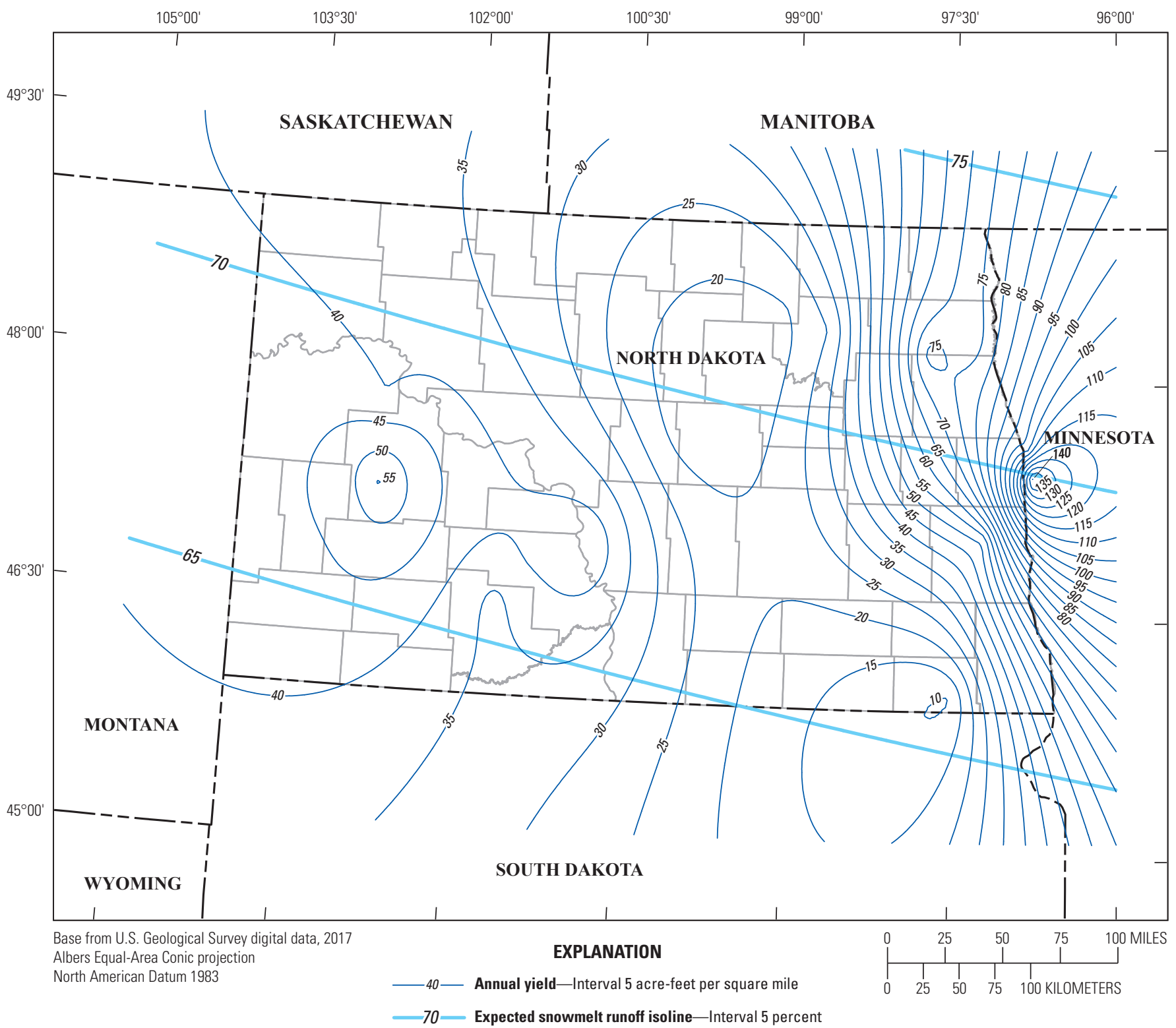

Figure 10. Annual yield at the 50-percent exceedance probability using 1931-2016 data with streamgages that have 10-percent or less missing annual volume record and 50 percent or less of Maintenance of Variance Extension Type III annual volume estimations and a drainage area of 505 square miles or less and allowing the 1931-2016 data to have a missing record for expected percentage of snowmelt runoff. $A$, missing 33 percent of record; $B$, missing 50 percent of record; $C$, missing 66 percent of record.—Continued 
A. Missing 33 percent of record

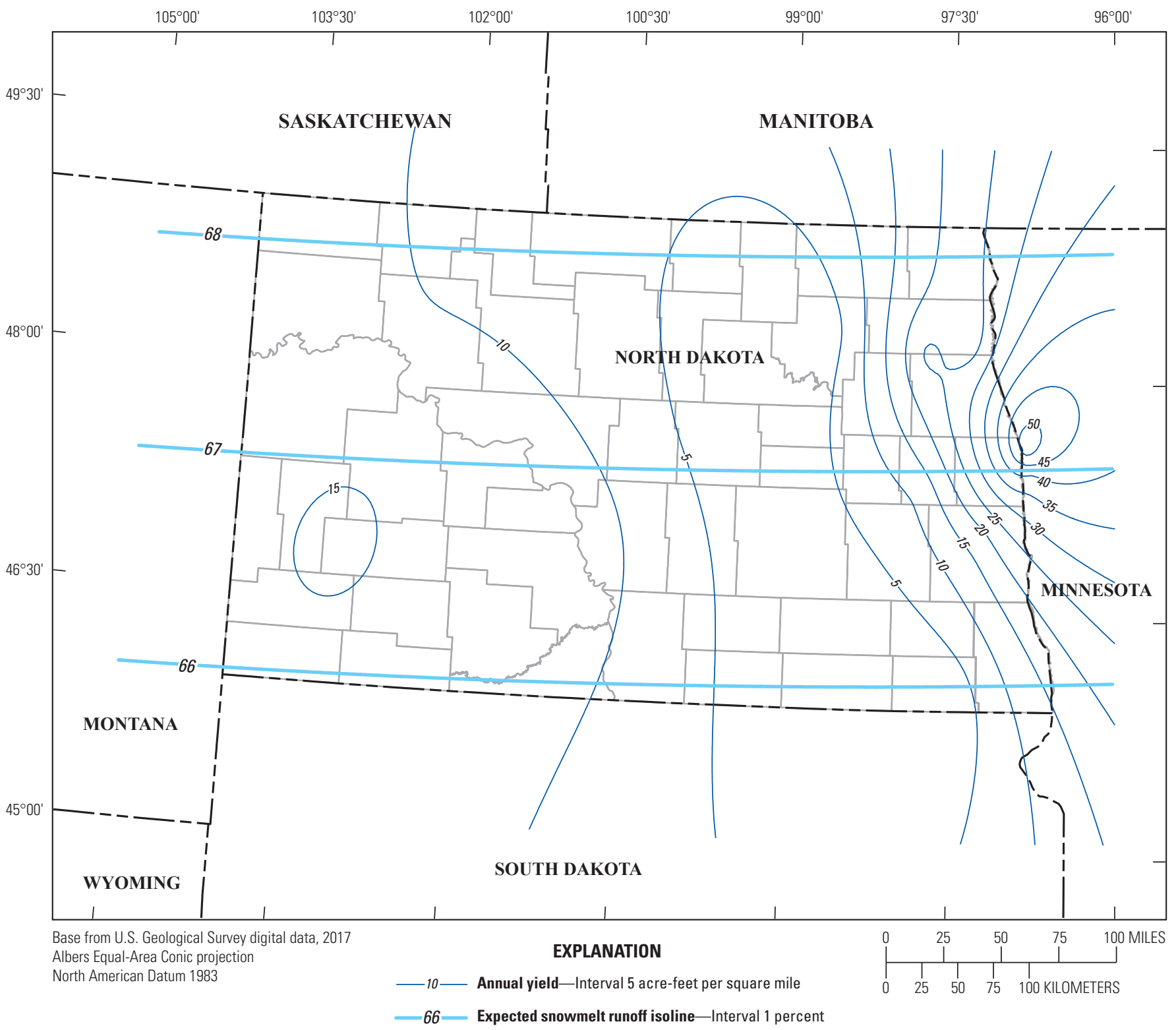

Figure 11. Annual yield at the 80-percent exceedance probability using 1931-2016 data with streamgages that have 10-percent or less missing annual volume record and 50 percent or less of Maintenance of Variance Extension Type III annual volume estimations and a drainage area of 505 square miles or less and allowing the 1931-2016 data to have a missing record for expected percentage of snowmelt runoff. $A$, missing 33 percent of record; $B$, missing 50 percent of record; $C$, missing 66 percent of record. 


\section{B. Missing 50 percent of record}

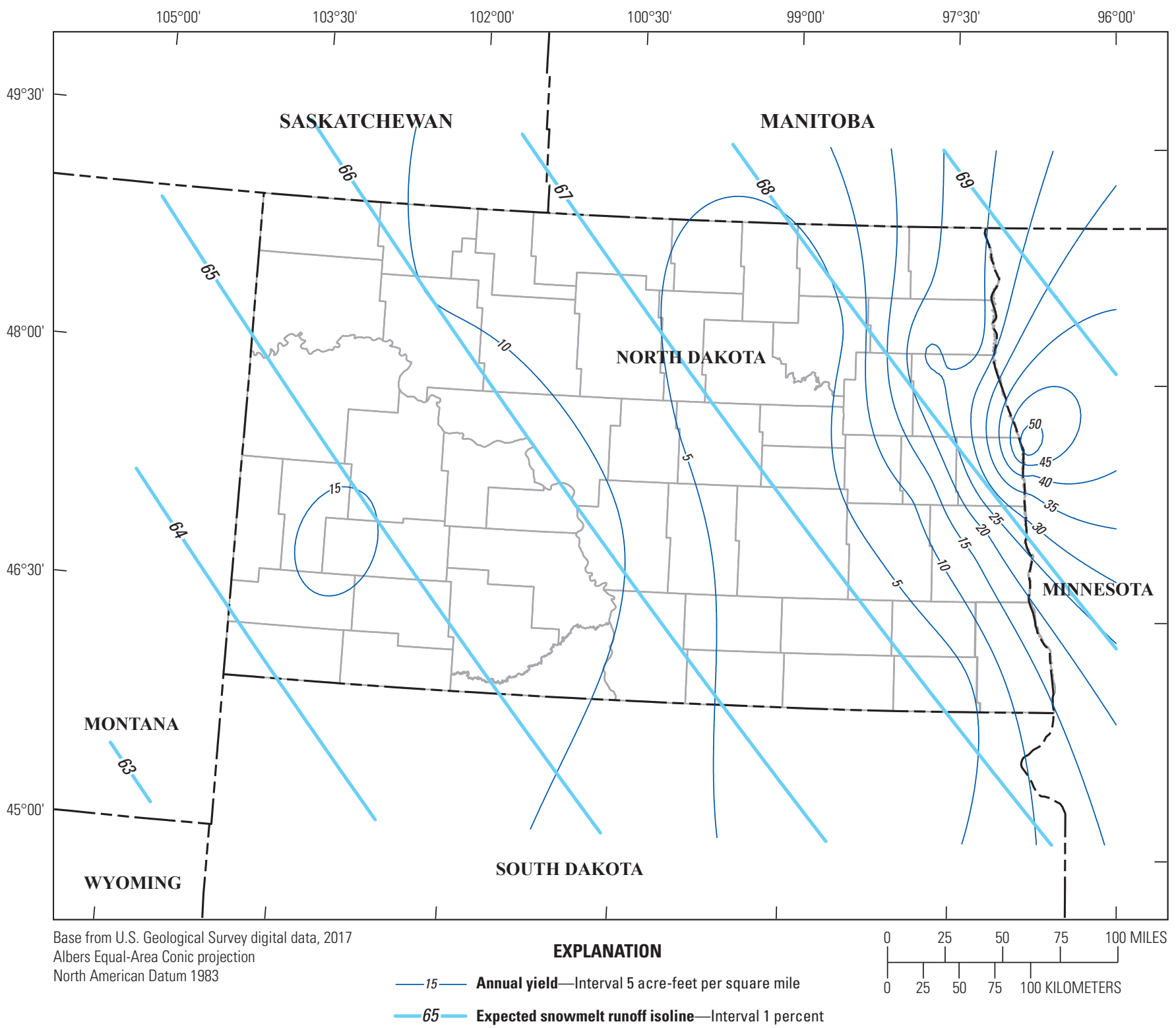

Figure 11. Annual yield at the 80-percent exceedance probability using 1931-2016 data with streamgages that have 10-percent or less missing annual volume record and 50 percent or less of Maintenance of Variance Extension Type III annual volume estimations and a drainage area of 505 square miles or less and allowing the 1931-2016 data to have a missing record for expected percentage of snowmelt runoff. $A$, missing 33 percent of record; $B$, missing 50 percent of record; $C$, missing 66 percent of record.-Continued 


\section{Missing 66 percent of record}

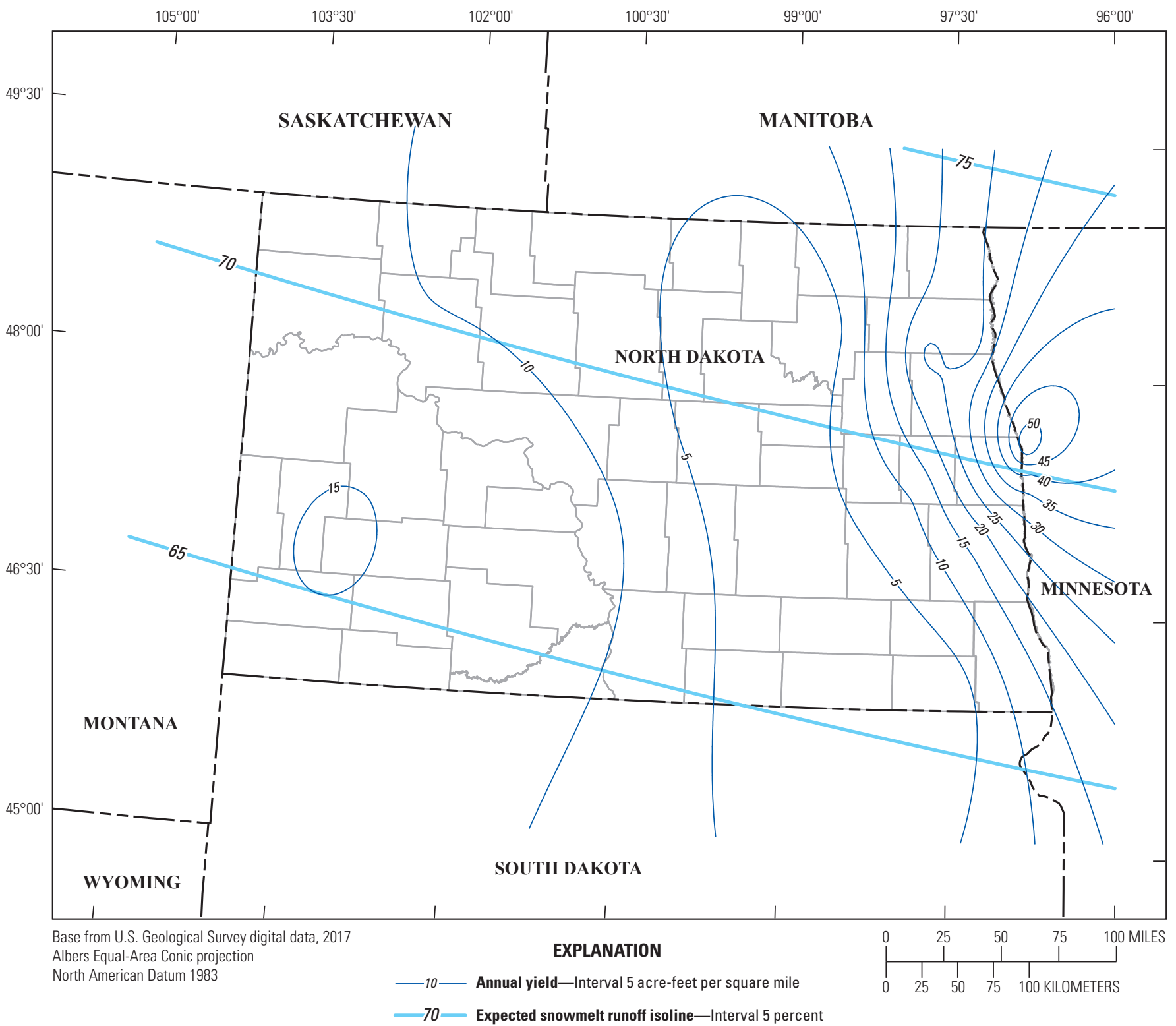

Figure 11. Annual yield at the 80-percent exceedance probability using 1931-2016 data with streamgages that have 10-percent or less missing annual volume record and 50 percent or less of Maintenance of Variance Extension Type III annual volume estimations and a drainage area of 505 square miles or less and allowing the 1931-2016 data to have a missing record for expected percentage of snowmelt runoff. $A$, missing 33 percent of record; $B$, missing 50 percent of record; $C$, missing 66 percent of record. - Continued 


\section{Summary}

The North Dakota hydrology manual prepared by the U.S. Department of Agriculture, Soil Conservation Service, presents methodologies used primarily for developing hydrology for onfarm conservation practices, watershed project, Resource Conservation and Development project measures, and river basin studies. The manual includes data necessary for determining hydrologic factors and developing a design discharge for a given site and intended purpose. The U.S. Geological Survey, in cooperation with the North Dakota Natural Resources Conservation Service, developed methods to reproduce and update the annual yield maps for chapter 7 of the North Dakota hydrology manual. Annual yields, in acre-feet per square mile, were estimated for the 50-percent and 80-percent exceedance probabilities using a Weibull plotting formula and U.S. Geological Survey streamflow data for the 1931-2016 period of record for 131 selected streamgages in North Dakota and parts of Montana, South Dakota, and Minnesota. Streamgages used in generating the final maps were restricted to sites with drainage areas of 505 square miles or less. Missing years of annual streamflow volume were estimated with the application of a modified Maintenance of Variance Extension Type III procedure. Maps generated using streamgages that had 10-percent or less missing annual volume record and 50 percent or less of the period of record (1931-2016) annual volumes estimated by Maintenance of Variance Extension Type III showed less contouring problems of steep gradients caused by large and small percentage exceedance probabilities for streamgages that are near each other. Expected percentage of snowmelt runoff isolines were estimated using High Plains Climatic Center precipitation and snowmelt data from 1931 to 2016 for 85 selected climatic sites and using U.S. Geological Survey streamflow data from 1931 to 2016 for 131 selected streamgages and were compared. The final expected percentage of snowmelt runoff isolines were estimated using streamflow data instead of precipitation and snowfall depth data. A snowmelt runoff seasonal period of March-May produced isolines that better approximated those of the original chapter 7 maps than a November-May runoff period. Expected percentage of snowmelt runoff isolines were sensitive to amounts of missing period of record. Suitable isoline slopes resulted when a missing period of record was set to 50 percent (43 years) and 66 percent (57 years) for the 86-year period of 1931-2016.

\section{References Cited}

Golden Software, 2018, Surfer 15: Golden Software software release, accessed on November 26, 2018, at https://www. goldensoftware.com/products/surfer.
High Plains Regional Climate Center, 2018, High Plains Regional Climate Center: High Plains Regional Climate Center web page, accessed April 2, 2018, at https://hprcc. unl.edu/.

Loucks, D.P., Stedinger, J.R., and Haith, D.A., 1981, Water resource systems planning and analysis: Englewood Cliffs, N.J., Prentice-Hall, Inc., 559 p.

National Weather Service, 2019, What are snow ratios?: National Oceanic and Atmospheric Administration web page, accessed February 26, 2019, at https://www.weather. gov/arx/why_snowratios.

Natural Resources Conservation Service, 2009, Watershed yield, chap. 20 of NEH Part 630 National Engineering Handbook: U.S. Department of Agriculture, Natural Resources Conservation Service, accessed May 9, 2017, at https:/www.nrcs.usda.gov/wps/portal/nrcs/detailfull/ national/water/?\&cid=stelprdb1043063.

Oliver, M.A., and Webster, R., 1990, Kriging-A method of interpolation for geographical information systems: International Journal of Geographical Information Systems, v. 4, no. 3, p. 313-332, accessed March 28, 2019, at https://doi. org/10.1080/02693799008941549.

Sando, S.K., and McCarthy, P.M., 2018, Methods for peakflow frequency analysis and reporting for streamgages in or near Montana based on data through water year 2015: U.S. Geological Survey Scientific Investigations Report 2018-5046, 39 p., accessed August 31, 2018, at https://doi. org/10.3133/sir20185046.

Soil Conservation Service, 1974, North Dakota hydrology manual: U.S. Department of Agriculture, accessed May 8, 2107, at https://www.nrcs.usda.gov/wps/portal/nrcs/detail/ nd/technical/engineering/?cid=stelprdb1269592.

U.S. Geological Survey, 2017, USGS water data for the Nation: U.S. Geological Survey National Water Information System database, accessed May 23, 2017, at https://doi.org/ 10.5066/F7P55KJN.

U.S. Geological Survey, 2018, StreamStats-Streamflow statistics and spatial analysis tools for water-resources applications: U.S. Geological Survey web page, accessed November 26, 2018, at https://water.usgs.gov/osw/streamstats/.

Vogel, R.M., and Stedinger, J.R., 1985, Minimum variance streamflow record augmentation procedures: Water Resources Research, v. 21, no. 5, p. 715-723, accessed November 26, 2018, at https://doi.org/10.1029/WR021i005p00715.

Williams-Sether, T., 2015, Regional regression equations to estimate peak-flow frequency at sites in North Dakota using data through 2009: U.S. Geological Survey Scientific Investigations Report 2015-5096, 12 p., accessed January 9, 2018, at https://doi.org/10.3133/sir20155096. 


\section{Appendix 1. Methods Used to Generate and Adjust Annual Streamflow Volumes Used in Move.3}

This appendix contains an Excel spreadsheet (available for download at https://doi.org/10.3133/sir20195144) that shows an example of computations used to generate annual streamflow volumes (by water year) and the ratio method used to adjust streamflow volumes for years with less than full year records. The spreadsheet contains two tabs; tab 1 is a listing of U.S. Geological Survey National Water Information System daily mean streamflow from 1956 to 2016 for U.S. Geological Survey station 05056100 (U.S. Geological Survey, 2017), and tab 2 shows the computations used to generate the final annual streamflow volumes that were used in the MOVE. 3 analysis.

Table 1.1. Example data and computations for U.S. Geological Survey station 05056100 (available for download at https://doi.org/10.3133/sir20195144).

\section{Reference Cited}

U.S. Geological Survey, 2017, USGS water data for the Nation: U.S. Geological Survey National Water Information System database, accessed May 23, 2017, at https://doi. org/10.5066/F7P55KJN. 


\section{Appendix 2. R Code Script and Supporting Data for the Modified Maintenance of Variance Extension Type III, MOVE.3, Application}

This appendix contains a link to a zipped folder, MOVE3_R-code, that has the readme text, example streamflow volumes input file, and $\mathrm{R}$ code script used in the MOVE.3 analysis. The files are available for download at https://doi.org/10.3133/sir20195144.

Although these data have been processed successfully on a computer system at the U.S. Geological Survey, no warranty expressed or implied is made regarding the display or utility of the data for other purposes, nor on all computer systems, nor shall the act of distribution constitute any such warranty. The U.S. Geological Survey or the U.S. Government shall not be held liable for improper or incorrect use of the data described and (or) contained herein. 
For more information about this publication, contact:

Director, USGS Dakota Water Science Center

821 East Interstate Avenue, Bismarck, ND 58503

1608 Mountain View Road, Rapid City, SD 57702

605-394-3200

For additional information, visit: https://www.usgs.gov/centers/dakotawater

Publishing support provided by the

Rolla Publishing Service Center 


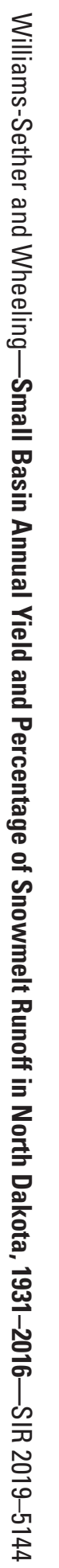

